\title{
Remote sensed and in situ constraints on processes affecting tropical tropospheric ozone
}

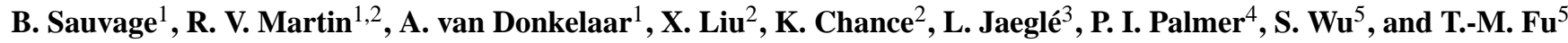 \\ ${ }^{1}$ Department of Physics and Atmospheric Science, Dalhousie University, Halifax, Nova Scotia, Canada \\ ${ }^{2}$ Atomic and Molecular Physics Division, Harvard-Smithsonian Center for Astrophysics, Cambridge, Massachusetts, USA \\ ${ }^{3}$ Department of Atmospheric Sciences, University of Washington, Seattle, Washington, USA \\ ${ }^{4}$ School of GeoSciences, University of Edinburgh, UK \\ ${ }^{5}$ Department of Earth and Planetary Sciences and Division of Engineering and Applied Sciences, Harvard University, \\ Cambridge, Massachusetts, USA
}

Received: 5 October 2006 - Published in Atmos. Chem. Phys. Discuss.: 17 November 2006

Revised: 7 February 2007 - Accepted: 12 February 2007 - Published: 14 February 2007

\begin{abstract}
We use a global chemical transport model (GEOSChem) to evaluate the consistency of satellite measurements of lightning flashes and ozone precursors with in situ measurements of tropical tropospheric ozone. The measurements are tropospheric $\mathrm{O}_{3}, \mathrm{NO}_{2}$, and $\mathrm{HCHO}$ columns from the GOME satellite instrument, lightning flashes from the OTD and LIS satellite instruments, profiles of $\mathrm{O}_{3}, \mathrm{CO}$, and relative humidity from the MOZAIC aircraft program, and profiles of $\mathrm{O}_{3}$ from the SHADOZ ozonesonde network. We interpret these multiple data sources with our model to better understand what controls tropical tropospheric ozone. Tropical tropospheric ozone is mainly affected by lightning $\mathrm{NO}_{\mathrm{x}}$ and convection in the upper troposphere and by surface emissions in the lower troposphere. Scaling the spatial distribution of lightning in the model to the observed flashes improves the simulation of $\mathrm{O}_{3}$ in the upper troposphere by 5-20 ppbv versus in situ observations and by $1-4$ Dobson Units versus GOME retrievals of tropospheric $\mathrm{O}_{3}$ columns. A lightning source strength of $6 \pm 2 \mathrm{Tg} N / \mathrm{yr}$ best represents in situ observations from aircraft and ozonesonde. Tropospheric $\mathrm{NO}_{2}$ and HCHO columns from GOME are applied to provide topdown constraints on emission inventories of $\mathrm{NO}_{\mathrm{x}}$ (biomass burning and soils) and VOCs (biomass burning). The topdown biomass burning inventory is larger than the bottom-up inventory by a factor of 2 for $\mathrm{HCHO}$ and alkenes, and by a factor of 2.6 for $\mathrm{NO}_{\mathrm{x}}$ over northern equatorial Africa. These emissions increase lower tropospheric $\mathrm{O}_{3}$ by $5-20 \mathrm{ppbv}$, improving the simulation versus aircraft observations, and by 4 Dobson Units versus GOME observations of tropospheric $\mathrm{O}_{3}$ columns. Emission factors in the a posteriori inventory are more consistent with a recent compilation from in situ measurements. The ozone simulation using two different dy-
\end{abstract}

Correspondence to: B. Sauvage

(bsauvage@fizz.phys.dal.ca) namical schemes (GEOS-3 and GEOS-4) is evaluated versus observations; GEOS-4 better represents $\mathrm{O}_{3}$ observations by $5-15$ ppbv, reflecting enhanced convective detrainment in the upper troposphere. Heterogeneous uptake of $\mathrm{HNO}_{3}$ on aerosols reduces simulated $\mathrm{O}_{3}$ by 5-7 ppbv, reducing a model bias versus in situ observations over and downwind of deserts. Exclusion of $\mathrm{HO}_{2}$ uptake on aerosols increases $\mathrm{O}_{3}$ by 5 ppbv in biomass burning regions, reducing a model bias versus MOZAIC aircraft measurements.

\section{Introduction}

Ozone $\left(\mathrm{O}_{3}\right)$ in the tropical troposphere is a major component of atmospheric radiative forcing (de Forster et al., 1997; Lacis et al., 1990) and plays a key role in the global oxidizing power of the atmosphere (Logan et al., 1981). Indeed tropical regions present high ultraviolet radiation and humidity that promote hydroxyl $(\mathrm{OH})$ creation through $\mathrm{O}_{3}$ photolysis (Thompson et al., 1992). Tropical tropospheric $\mathrm{O}_{3}$ production is limited by nitrogen oxides $\left(\mathrm{NO}_{\mathrm{x}}=\mathrm{NO}+\mathrm{NO}_{2}\right)$ emitted from biomass burning (Chatfield and Delany, 1990), biogenic sources, fossil fuel combustion, and lightning (Jacob et al., 1996). The motivation of this study is to better understand processes affecting tropical tropospheric $\mathrm{O}_{3}$, using a global chemical and transport model constrained with satellite and in situ data.

Considerable uncertainty remains in the magnitude and distribution of tropical $\mathrm{O}_{3}$ precursor emissions, such as $\mathrm{NO}_{\mathrm{x}}$ (Lee et al., 1997; Holland et al., 1999). Lightning produced $\mathrm{NO}_{\mathrm{x}}\left(\mathrm{L}-\mathrm{NO}_{\mathrm{x}}\right)$ are the most uncertain with recent estimates varying by an order magnitude from 1 to $13 \mathrm{Tg} \mathrm{N} / \mathrm{yr}$ (Nesbitt et al., 2000; Price et al., 1997). Lightning $\mathrm{NO}_{\mathrm{x}}$ emissions are largest over the Tropics, in the Inter Tropical Convergence

Published by Copernicus GmbH on behalf of the European Geosciences Union. 


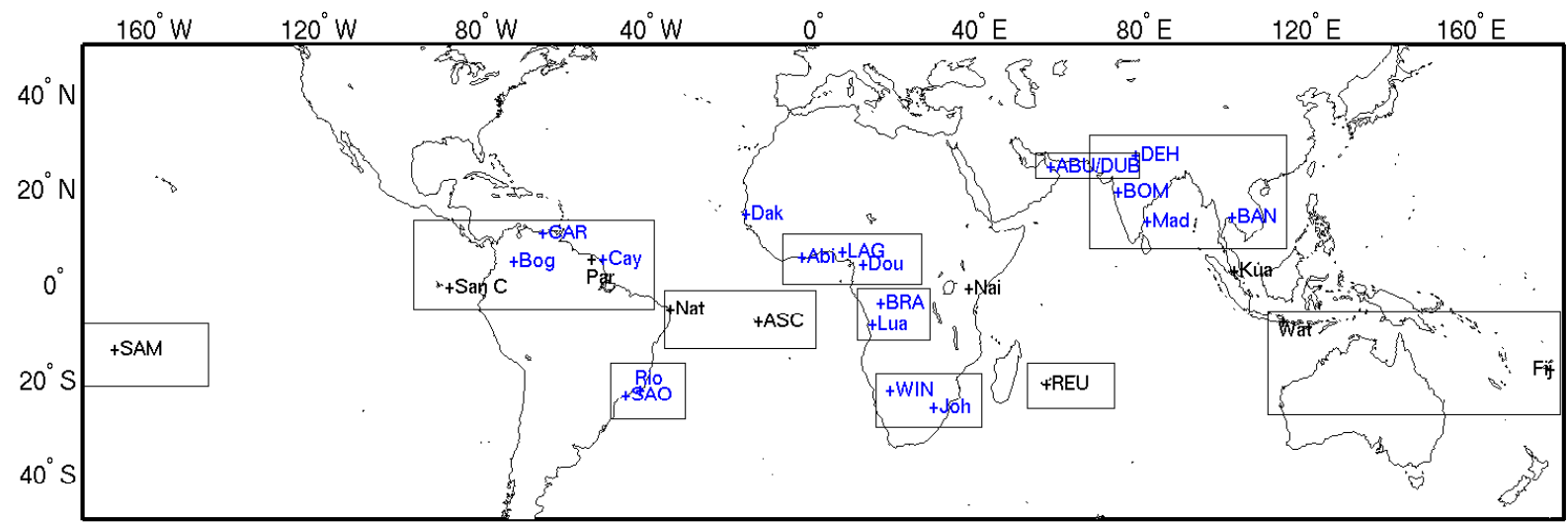

Fig. 1. MOZAIC (blue) and SHADOZ (black) sites used in this study. Capital letters refer to sites that are used here to represent the rectangular region. Abbreviations are defined in Table 1.

Zone (ITCZ) area (Christian et al., 2003), and are directly emitted into the free troposphere where long lifetimes and efficient $\mathrm{O}_{3}$ production make the $\mathrm{O}_{3}$ burden very sensitive to those emissions (Martin et al., 2002a). Surface sources from biomass burning and soils are also highly uncertain (around 3-13 Tg N/yr and 4-21 Tg N/yr respectively (Holland et al., 1999)). Soils have been highlighted to be an underestimated $\mathrm{NO}_{\mathrm{x}}$ source (Jaeglé et al., 2004). Biomass burning accounts for half of the global CO emissions (Andreae et al., 1993). Bottom-up estimates of these tropical emissions have been limited by the lack of measurements in this remote region.

The goal of the present study is motivated by 2 objectives: 1. use a global chemical transport model to evaluate the consistency of satellite measurements of lightning flash counts and $\mathrm{O}_{3}$ precursors with in situ measurements of tropospheric $\mathrm{O}_{3}$, and 2. interpret these multiple data sources with a global chemical transport model to better understand what controls tropical tropospheric $\mathrm{O}_{3}$. Indeed evaluation of satellite data has been limited over the tropics because of a lack of in situ measurements especially for $\mathrm{O}_{3}$ precursors. Understanding of tropical tropospheric $\mathrm{O}_{3}$ is also limited by current uncertainties on anthropogenic and natural $\mathrm{O}_{3}$ precursors sources, which can be readily inferred from satellite observations. Global measurements of nitrogen dioxide $\left(\mathrm{NO}_{2}\right)$ atmospheric concentrations from space provide a top-down constraint on $\mathrm{NO}_{\mathrm{x}}$ emissions (Martin et al., 2003a; Jaeglé et al., 2005; Leue et al., 2001). Tropospheric $\mathrm{NO}_{2}$ columns are closely related to surface $\mathrm{NO}_{\mathrm{x}}$ emissions since $\mathrm{NO}_{2}$ is the dominant form of $\mathrm{NO}_{\mathrm{x}}$ in the boundary layer and the $\mathrm{NO}_{\mathrm{x}}$ lifetime against oxidation in the tropical boundary layer is several hours. Similarly, volatile organic compounds (VOC) emissions, critical for understanding radical chemistry in the troposphere, can be constrained by formaldehyde (HCHO) columns measured from space (Palmer et al., 2003). Indeed HCHO is a high-yield product of VOC oxidation with a lifetime of hours (Sprengnether et al., 2002). Interpretation of these molecules is then fundamental to evaluate the loca- tion and intensity of $\mathrm{O}_{3}$ precursor emissions. In situ measurements from the Measurements of ozone and water vapor by in-service Airbus aircraft (MOZAIC) program (Marenco et al., 1998; Thouret et al., 2006) and the Southern Hemisphere Additional Ozonesondes SHADOZ network (Thompson et al., 2003a; 2003b) provide vertical profile information at higher resolution than is available from satellite. Few studies have used at the same time these different datasets, to better understand tropical tropospheric $\mathrm{O}_{3}$. A global chemical transport model is a useful tool to relate measurements from these disparate sources.

We provide an overview of the data in Sect. 2. A complete description of the GEOS-Chem global chemical transport model is in Sect. 3.1. Then we introduce the modified simulation used in this study, based on improvements described in the same Sect. 3.2. These improvements enable a better understanding of factors controlling tropical tropospheric $\mathrm{O}_{3}$. In Sect. 4, we first evaluate the simulation and integration of satellite information with in situ data and satellite data; then we assess the dynamical and chemical processes driving tropical tropospheric $\mathrm{O}_{3}$.

\section{Presentation and overview of the data}

The following measurements are used to evaluate and improve the GEOS-Chem chemical transport model.

\subsection{In situ data. Aircraft and ozonesonde measurements}

Since 1994, the MOZAIC aircraft program has been providing regular measurements of ozone (the overall precision is $\pm 2 \mathrm{ppbv}+2 \%$ ) and water vapor at high spatial and temporal resolution (Marenco et al., 1998). Current information is available at http://mozaic.aero.obs-mip.fr. Additional CO measurements have been made onboard five aircraft (Nédélec et al., 2003) since the end of 2000 with an overall precision of $\pm 5 \mathrm{ppbv}, \pm 5 \%$. Table 1 contains char- 
Table 1. Characteristics of the MOZAIC and SHADOZ sites. Abbreviations are given in parenthesis. Number of CO measurements are given in parenthesis where available.

\begin{tabular}{|c|c|c|c|}
\hline Site & Lon/Lat & $\begin{array}{c}\text { Total number of } \mathrm{O}_{3} \\
\text { and } \mathrm{RH} \text { profiles }\end{array}$ & Region \\
\hline Caracas (CAR) & $67.0^{\circ} \mathrm{W} / 10.5^{\circ} \mathrm{N}$ & 651 & northern South America \\
\hline Cayenne (Cay) & $52.3^{\circ} \mathrm{W} / 4.9^{\circ} \mathrm{N}$ & 175 & northern South America \\
\hline Bogota (Bog) & $74.0^{\circ} \mathrm{W} / 4.5^{\circ} \mathrm{N}$ & 220 & northern South America \\
\hline San Cristobal (San C) & $89.6^{\circ} \mathrm{W} / 0.9^{\circ} \mathrm{S}$ & 256 & northern South America \\
\hline Paramaribo (Par) & $55.2^{\circ} \mathrm{W} / 5.8^{\circ} \mathrm{N}$ & 230 & northern South America \\
\hline Rio de Janeiro (Rio) & $43.2^{\circ} \mathrm{W} / 22.8^{\circ} \mathrm{S}$ & 551 & South America \\
\hline Sao Paolo (SAO) & $46.6^{\circ} \mathrm{W} / 23.5^{\circ} \mathrm{S}$ & 979 & South America \\
\hline Dakar (Dak) & $17.4^{\circ} \mathrm{W} / 14.5^{\circ} \mathrm{N}$ & 89 & north Africa \\
\hline Lagos (LAG) & $3.3^{\circ} \mathrm{E} / 6.5^{\circ} \mathrm{N}$ & 354 (139) & West Africa \\
\hline Abidjan (Abi) & $4.0^{\circ} \mathrm{W} / 5.4^{\circ} \mathrm{N}$ & 178 & West Africa \\
\hline Douala (Dou) & $9.7^{\circ} \mathrm{E} / 4.0^{\circ} \mathrm{N}$ & 185 & West Africa \\
\hline Brazzaville (BRA) & $15.3^{\circ} \mathrm{E} / 4.2^{\circ} \mathrm{S}$ & 114 & Central Africa \\
\hline Luanda (Lua) & $13.2^{\circ} \mathrm{E} / 8.5^{\circ} \mathrm{S}$ & 48 & Central Africa \\
\hline Windhoek (Win) & $17.4^{\circ} \mathrm{E} / 22.4^{\circ} \mathrm{S}$ & 138 & South Africa \\
\hline Johannesburg (Joh) & $28.0^{\circ} \mathrm{E} / 26.2^{\circ} \mathrm{S}$ & 574 & South Africa \\
\hline Nairobi (Nai) & $36.7^{\circ} \mathrm{E} / 1.1^{\circ} \mathrm{S}$ & 116 & East Africa \\
\hline Abu Dhabi (Abu) & $54.6^{\circ} \mathrm{E} / 24.4^{\circ} \mathrm{N}$ & 215 & Middle East \\
\hline Dubai (DUB) & $55.3^{\circ} \mathrm{E} / 25.2^{\circ} \mathrm{N}$ & $559(89)$ & Middle East \\
\hline Bombay (BOM) & $72.8^{\circ} \mathrm{E} / 19.0^{\circ} \mathrm{N}$ & 145 & India \\
\hline Delhi (DEL) & $77.3^{\circ} \mathrm{E} / 28.5^{\circ} \mathrm{N}$ & $678(274)$ & India \\
\hline Madras (Mad) & $80.0^{\circ} \mathrm{E} / 13.0^{\circ} \mathrm{N}$ & 246 & India \\
\hline Bangkok (BAN) & $100.5^{\circ} \mathrm{E} / 13.9^{\circ} \mathrm{N}$ & 659 & Thailand \\
\hline Natal (Nat) & $35.3^{\circ} \mathrm{W} / 5.4^{\circ} \mathrm{S}$ & 253 & Atlantic \\
\hline Ascension (ASC) & $14.4^{\circ} \mathrm{W} / 7.9^{\circ} \mathrm{S}$ & 305 & Atlantic \\
\hline Reunion Island (REU) & $55.4^{\circ} \mathrm{E} / 21.0^{\circ} \mathrm{S}$ & 146 & Indian Ocean \\
\hline Kuala Lumpur (Kua) & $112.6^{\circ} \mathrm{E} /-7.5^{\circ} \mathrm{S}$ & 160 & Pacific \\
\hline Fiji (Fij) & $178^{\circ} \mathrm{E} / 18.0^{\circ} \mathrm{S}$ & 229 & Pacific \\
\hline Samoa (SAM) & $170.5^{\circ} \mathrm{W} / 14.2^{\circ} \mathrm{S}$ & 263 & Pacific \\
\hline
\end{tabular}

acteristics of the MOZAIC sites, with their locations shown in Fig. 1 in blue. We use profiles over 19 of the 30 cities sampled by the MOZAIC program between $30^{\circ} \mathrm{N}-30^{\circ} \mathrm{S}$, the most sampled ones, with 15 to 60 flights per month for a site. This corresponds to a total of 6750 flights over all regions.

We analyze the data in monthly average for the 1994-2005 period, except for West Africa where measurements began in 2001 (Sauvage et al., 2005). For each site, we remove data within $15 \mathrm{~km}$ of a site, to avoid local pollution that is not representative of the broader region. This criterion removes the lowest $25-50 \mathrm{hPa}$.

The SHADOZ network complements the MOZAIC coverage as shown in Fig. 1 in black. It provides regular ozonesonde measurements (Thompson et al., 2003a,b), at different tropical stations, at least twice a month. Further details can be found on the SHADOZ Web site: http://croc. gsfc.nasa.gov/shadoz/. We use measurements over the 19982004 period.

For clarity and conciseness, we present a subset representative of the broader region indicated by the black rectangle in Fig. 1. We also examined other sites within each region, and found similar features.

\subsection{Space-based observations. The LIS, OTD and GOME instruments}

The Optical Transient Detector (OTD) (Boccippio et al., 2000b) was launched in 1995 on the MicroLab-1 satellite. The OTD spatial resolution is $10 \mathrm{~km}$ over a field of view of $1300 \mathrm{~km} \times 1300 \mathrm{~km}$. The OTD detects both intra-cloud (IC) and cloud-to-ground (CG) discharges during day and night conditions. The Lightning Imaging sensor (LIS) was launched in 1997 aboard the Tropical Rainfall Measuring Mission (TRMM) Observatory into a nearly circular orbit inclined 35 degrees. It detects lightning with storm-scale resolution of $3-6 \mathrm{~km}$ ( 3 at nadir, 6 at limb) over $550 \times 550 \mathrm{~km}$. The system is able to detect weak lightning (Christian et al., 1989).

The Global Ozone Monitoring Experiment (GOME) (Burrows et al., 1999) instrument onboard the European Re- 
mote Sensing- 2 satellite provided the capability for continuous global monitoring of $\mathrm{O}_{3}, \mathrm{NO}_{2}$ and $\mathrm{HCHO}$ atmospheric columns through observation of solar backscatter over 19952003. GOME observes the atmosphere in the nadir view with a $40 \mathrm{~km}$ along track by $320 \mathrm{~km}$ across track. Global coverage is achieved every 3 days with an overpass time over the tropics between 10-11 local time (crossing the equator at 1030 local time). In this work we use GOME measurements for the year 2000.

We begin with tropospheric $\mathrm{NO}_{2}$ line-of-sight (slant) columns retrieved from the GOME observations by Martin et al. (2002b) version 2 (Guerova et al., 2006), and HCHO slant columns retrieved by Chance et al. (2000). Following Palmer et al. (2001) we calculate vertical columns by applying an air mass factor (AMF) algorithm to account for atmospheric scattering. The AMF is computed as the integral of the relative vertical distribution of the trace gas (shape factor), weighted by the altitude dependent scattering weights computed from the LIDORT radiative transfer model (Spurr et al., 2002). Coincident $\mathrm{NO}_{2}$ and $\mathrm{HCHO}$ shape factors are from the modified GEOS-Chem simulation described in Sect. 3. The cloud correction uses local cloud information from GOME (Kurosu et al., 1999) as described in Martin et al. (2002b). The aerosol correction uses aerosol profiles from the GEOS-Chem model following Martin et al. (2003a). The stratospheric $\mathrm{NO}_{2}$ column is removed using observations over the central Pacific where there is little tropospheric $\mathrm{NO}_{2}$, and subtracting the corresponding column from the ensemble of GOME scenes for the appropriate latitude and month. The result is corrected for the small amount of tropospheric $\mathrm{NO}_{2}$ over the Pacific. Variability in the stratospheric $\mathrm{NO}_{2}$ columns is accounted for using assimilated stratospheric $\mathrm{NO}_{2}$ columns from Boersma et al. (2004), a minor issue in the Tropics.

Martin et al. (2004) evaluated the GOME retrieval with airborne in situ measurements of $\mathrm{NO}_{2}$ and $\mathrm{HCHO}$ over the Southeastern United States. Uncertainties include absolute errors of $1 \times 10^{15}$ molecules $\mathrm{cm}^{-2}$ for tropospheric $\mathrm{NO}_{2}$ (Martin et al., 2002b) and $4 \times 10^{15}$ molecules $\mathrm{cm}^{-2}$ for HCHO (Chance et al., 2000) from the spectral fitting, the stratospheric $\mathrm{NO}_{2}$ column and instrument artifacts. Other uncertainties arising from the AMF calculation include random and systematic contributions from surface reflectivity, clouds, aerosols, and the trace gas profile (Martin et al., 2003a; Boersma et al., 2004). The monthly mean uncertainty is $\pm\left(5 \times 10^{14}\right.$ molecules $\left.\mathrm{cm}^{-2}+30 \%\right)$ for tropospheric $\mathrm{NO}_{2}$ and a $30 \%$ (Millet et al., 2006) error on the HCHO column retrieval that increases in the presence of biomass burning aerosol (Fu et al., 2007). van Noije et al. (2006) compared three different retrievals of tropospheric $\mathrm{NO}_{2}$ columns from GOME, and found the greatest degree of consistency in the tropics, well within the error estimates reported here.

For $\mathrm{O}_{3}$, we use version 2 of the tropospheric $\mathrm{O}_{3}$ columns retrieved by Liu et al. (2005). The retrieval uses an optimal estimation method (Rodgers, 2000). GOME retrievals and GEOS-Chem simulations are mapped onto a common regular grid. For each grid cell we apply GOME averaging kernels (Liu et al., 2006) to GEOS-Chem ozone profiles, to get the convolved GEOS-CHEM TOC. For all GOME molecules, we exclude observations in which the fraction of backscattered intensity from clouds exceeds 50\% of a GOME scene.

\section{General description of the GEOS-Chem model - orig- inal and modified versions}

A global 3-D model of tropospheric chemistry provides a quantitative tool to assess the processes affecting tropospheric ozone. We use the GEOS-Chem chemical and transport model (Bey et al., 2001). In the following we first introduce the original model version (7-02-04 http://www-as. harvard.edu/chemistry/trop/geos/index.html). Then we describe the "modified" simulation, focusing on developments to improve the original simulation.

\subsection{Original version}

The model is driven by assimilated meteorological data for 2000 from the Goddard Earth Observing System (GEOS4) at the NASA Global Modeling and Assimilation Office (GMAO). The model version has 30 vertical sigma-levels (surface to $0.1 \mathrm{hPa}$ ), and a horizontal resolution of $1^{\circ}$ latitude by $1.25^{\circ}$ longitude, which can be degraded to $2^{\circ}$ latitude by $2.5^{\circ}$ longitude and $4^{\circ}$ latitude by $5^{\circ}$ longitude for computational expediency. We use the latter two resolutions in the study. The data have 6-hour temporal resolution (3-hour for surface variables and mixing depth). We present sensitivity simulations using GEOS-3 as discussed in Sect. 4.4.

The GEOS-Chem model includes a detailed simulation of tropospheric $\mathrm{O}_{3}-\mathrm{NO}_{\mathrm{x}}$-hydrocarbon chemistry as well as of aerosols and their precursors, using 41 tracers, around 90 species, and 300 reactions. The model presently includes sulfate, nitrate, ammonium, black and organic carbon, mineral dust and sea salt (Park et al., 2004, 2005; Alexander et al., 2005; Fairlie et al., 2007). The aerosol and gaseous simulations are coupled through formation of sulfate and nitrate, $\mathrm{HNO}_{3}(\mathrm{~g}) / \mathrm{NO}_{3}{ }^{-}$partitioning of total inorganic nitrate, heterogeneous chemistry on aerosols (Jacob, 2000; Evans et al., 2005), and aerosol effects on photolysis rates (Martin et al., 2003b).

Table 2 contains annual global $\mathrm{NO}_{\mathrm{x}}$ emissions used in the model. Soil $\mathrm{NO}_{\mathrm{x}}$ emissions are computed using a modified version of the algorithm of Yienger and Levy (1995) with the canopy reduction factors described in Wang et al. (1998). The biomass burning inventory is based on estimates of biomass burned from Lobert et al. (1999), emission factors from Staudt et al. (2003), interannual variation inferred from satellite observations of fires by Duncan et al. (2003), as implemented by Martin et al.(2002). Emissions of lightning 
$\mathrm{NO}_{\mathrm{x}}$ are linked to deep convection following the parameterization of Price et al. (1992) with vertical profiles from Pickering et al. (1998) as implemented by Wang et al. (1998). The northern midlatitude lightning source is prescribed as 1.6 $\mathrm{Tg} \mathrm{N} \mathrm{yr}^{-1}$ for consistency with INTEX-A aircraft obervations (Hudman et al., 2007; Martin et al., 2007) and cloudscale modeling (DeCaria et al., 2005; Off et al., 2007).

The model has been previously applied to interpret satellite observations of HCHO (Palmer et al., 2001, 2003, 2006; Shim et al., 2005; Millet et al., 2006), $\mathrm{NO}_{2}$ (Martin et al., 2002b, 2003a; Jaeglé et al., 2004, 2005; Guerova et al., 2006), and tropospheric $\mathrm{O}_{3}$ (Martin et al., 2002a; Chandra et al., 2002, 2003; Kim et al., 2005; Liu et al., 2006). However, none of these studies examined all three species together.

\subsection{Modified version}

In the following section we present several developments which are necessary for accurate understanding and evaluation of the processes affecting tropical tropospheric $\mathrm{O}_{3}$ described in Sect. 4. These improvements deal with emissions and heterogeneous chemistry that are included in our modified simulation. GOME observations of $\mathrm{NO}_{2}$ and $\mathrm{HCHO}$ are applied to constrain surface emissions of $\mathrm{NO}_{\mathrm{x}}$ and VOCs. Lightning flash counts are used to better represent its spatial distribution. Heterogeneous chemistry on aerosols is updated to reflect recent measurements.

\subsubsection{Soil $\mathrm{NO}_{\mathrm{x}}$ emissions}

Strong signals from soil $\mathrm{NO}_{\mathrm{x}}$ emissions are apparent in satellite observations of tropospheric $\mathrm{NO}_{2}$ columns (Bertram et al., 2005). We use the a posteriori soil $\mathrm{NO}_{\mathrm{x}}$ emission inventory derived from GOME observations of $\mathrm{NO}_{2}$ columns via inverse modeling with GEOS-Chem model by Jaeglé et al. (2005) for the year 2000. They used the spatio-temporal distribution of remotely sensed fires and a priori inventory information on the locations of regions dominated by fuel combustion to partition among the different $\mathrm{NO}_{\mathrm{x}}$ sources. The resulting annual tropical soil emissions are $35 \%$ higher in the a posteriori inventory (Table 2) and account for $22 \%$ of tropical $\mathrm{NO}_{\mathrm{x}}$ emissions. During March-April-May (MAM) and June-July-August (JJA), emissions increase by a factor of 3 over tropical ecosystems of Africa, reflecting a better constraint on $\mathrm{NO}_{\mathrm{x}}$ emissions associated with the monsoon (Jaeglé et al., 2004). Emissions increase by $20 \%$ during the rainy season over South America, and the agricultural region of North India.

\subsubsection{Biomass burning emissions of $\mathrm{NO}_{\mathrm{x}}$ and VOCs}

We apply tropospheric $\mathrm{NO}_{2}$ and $\mathrm{HCHO}$ columns retrieved from GOME to provide top-down constraints on regional biomass burning emissions of $\mathrm{NO}_{\mathrm{x}}$ and reactive VOCs. Richter et al. (2002) found a strong signal from biomass burning in the GOME $\mathrm{NO}_{2}$ columns. Our inversion for
Table 2. Annual $\mathrm{NO}_{\mathrm{x}}$ emissions in the GEOS-Chem simulations for the year 2000. The tropical emissions are over $20^{\circ} \mathrm{S}-20^{\circ} \mathrm{N}$

\begin{tabular}{lcc}
\hline Source & $\begin{array}{c}\text { Original, Global/Tropics } \\
\text { (Tg N/yr) }\end{array}$ & $\begin{array}{c}\text { modified, Global/Tropics } \\
\text { (Tg N/yr) }\end{array}$ \\
\hline Biomass Burning & $5.9 / 4.0$ & $7.0 / 5.0$ \\
Lightning & $6.0 / 3.3$ & $6.0 / 3.3$ \\
Soils & $6.0 / 2.3$ & $8.9 / 3.1$ \\
Anthropogenic & $23.9 / 2.1$ & $23.9 / 2.1$ \\
Biofuels & $2.2 / 0.7$ & $2.2 / 0.7$ \\
Aircraft & $0.5 / 0.1$ & $0.5 / 0.1$ \\
\hline
\end{tabular}

biomass burning $\mathrm{NO}_{\mathrm{x}}$ is conducted after application of the a posteriori soil $\mathrm{NO}_{\mathrm{x}}$ inventory from Jaeglé et al. (2005). The $\mathrm{NO}_{\mathrm{x}}$ inversion accounts for the local $\mathrm{NO}_{2} / \mathrm{NO}$ ratio and the local $\mathrm{NO}_{\mathrm{x}}$ lifetime following Martin et al. (2003a). The inversion is applied here at regional scale in the form of $\mathrm{NO}_{\mathrm{x}}$ emission factors that should be applicable to simulations for other years.

Figure 2 shows the seasonal $\mathrm{NO}_{\mathrm{x}}$ biomass burning emissions arising from the a priori (left) and top-down (right) inventories. Annual tropical $\mathrm{NO}_{\mathrm{x}}$ emissions are $30 \%$ higher in the top-down versus the a priori (Table 2). $\mathrm{NO}_{\mathrm{x}}$ emissions from Africa and eastern regions increase by $30 \%$, whereas they decrease from South America by $30 \%$. The largest absolute difference occurs in DJF over Northern Africa with topdown emissions of $3.84 \mathrm{Tg} \mathrm{N} / \mathrm{yr}$ compared to $1.64 \mathrm{Tg} \mathrm{N} / \mathrm{yr}$, likely reflecting emission factors that were too low in the original simulation. There is also a $15 \%$ increase in emissions from Central/South Africa during JJA to $4.24 \mathrm{Tg} \mathrm{N} / \mathrm{yr}$.

Palmer et al. (2003) showed that HCHO columns over North America are closely related to isoprene emissions, and exploited that relationship to infer continental isoprene emissions from the GOME HCHO columns. Meyer-Arnek et al. (2005) found signals in the GOME HCHO columns from both biogenic and pyrogenic sources over Africa. Shim et al. (2005) extended the approach of Palmer et al. (2003) to infer global isoprene emissions, but found that large increases in biomass burning emissions were necessary to reconcile the GOME observations. More recently, Fu et al. (2007) found over East and South East Asia a biomass burning source derived from GOME almost 5 times the estimate of a bottomup emission inventory. We similarly find over the tropics an underestimate of more than a factor two in the GEOS-Chem $\mathrm{HCHO}$ columns during biomass burning. Neither scaling of the current GEIA isoprene emission inventory, nor application of the recently developed MEGAN inventory (Guenther et al., 2006), was able to account for the discrepancy without introducing biases outside of the biomass burning season. A recent compilation by Andreae (personal communication, 2005) of in situ measurements of emission factors contain values that are higher than those used in GEOS-Chem for 

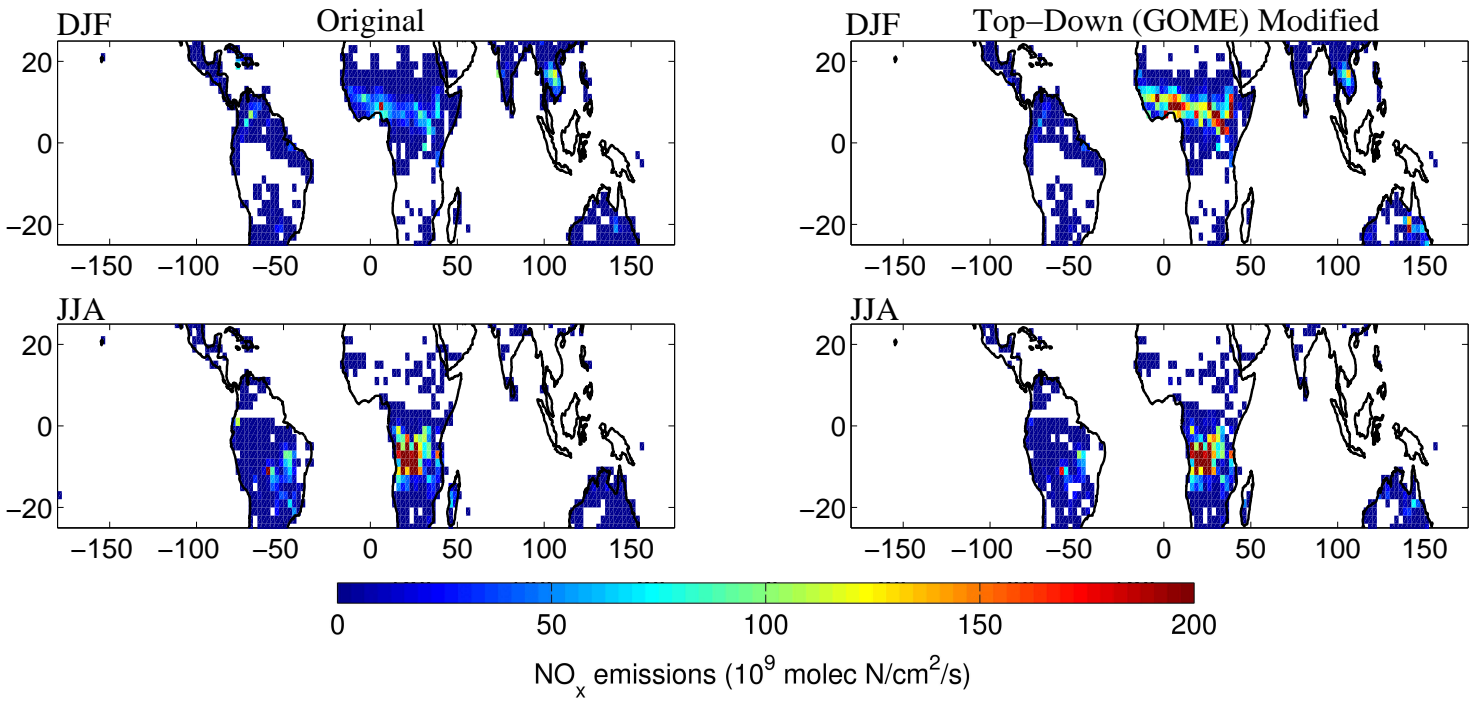

Fig. 2. Seasonal biomass burning emissions $\left(10^{9}\right.$ molec $\left.\mathrm{N} \mathrm{cm}^{-2} \mathrm{~s}^{-1}\right)$ for December-February (DJF) and June-August (JJA). The left panels represent emissions used in the original simulation. The right panels represent top-down emissions determined from GOME observations of tropospheric $\mathrm{NO}_{2}$ columns.

$\mathrm{HCHO}$ and alkenes. We tentatively attribute the regional difference between GOME and GEOS-Chem HCHO columns to biomass burning emissions of alkenes and $\mathrm{HCHO}$, and calculate a tropical mean emission ratio for reactive VOCs emissions that is a factor of 2 larger for both species.

\subsubsection{Lightning $\mathrm{NO}_{\mathrm{x}}$ emissions}

We use space-based observations of lightning flash counts from the seasonally varying climatological OTD/LIS (Boccippio et al., 2000a, 2001) dataset (High Resolution Annual Climatology - HRAC - data) to constrain GEOS-Chem lightning flashes, by applying a local seasonal rescaling factor, R:

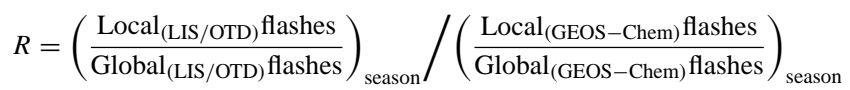

This approach is motivated by the seasonal latitudinal variation in tropical lightning activity that is not well represented by the GEOS fields. The seasonal scale factor is applied to a 10-year average of the simulated and observed flashes, such that inter-annual variability of the lightning $\mathrm{NO}_{\mathrm{x}}$ emissions as represented by the model is retained. The climatology is a $0.5^{\circ} \times 0.5^{\circ}$ gridded composite of total intra-cloud and cloud-to-ground ( $\mathrm{IC}+\mathrm{CG}$ ) lightning bulk production over 1995-2004. Lowpass temporal filtering of 110 days for the combined LIS/OTD is applied. Observations in the LIS/OTD v1.0 reanalysis have been corrected by the LIS Science Team for flash detection efficiency, applied as a function of sensor, viewing time, date of mission, and (for OTD) geographic location. For the entire dataset, these corrections correspond to average flash detection efficiencies of $47 \%$ (OTD) and $82 \%$ (LIS) (Boccippio et al., 2002; Christian et al., 2003). The adjustments derive from a combination of laboratory calibration, ground validation, and cross-normalization between OTD and LIS. The uncertainty in these corrections is $\pm 10 \%$.

Figure 3 shows the seasonal average lightning $\mathrm{NO}_{\mathrm{x}}$ emissions $\left(\mathrm{L}-\mathrm{NO}_{\mathrm{x}}\right)$ during DJF and JJA, for the original (left), and modified (right) simulations. The LIS/OTD seasonal climatologies and the improved $\mathrm{L}-\mathrm{NO}_{\mathrm{x}}$ emissions in GEOSChem exhibit higher spatio-temporal correlations $\left(r^{2}=0.97-\right.$ $0.98)$ than in the original simulation $\left(r^{2}=0.4-0.57\right)$. Annual emissions are unchanged (Table 2). However substantial regional differences are inferred by the local rescaling. Emissions decrease over Africa by $16 \%$, over South America by $42 \%$, and increase from the Eastern tropics by $55 \%$ (mostly over Australia). During JJA, continental L-NO $\mathrm{NO}_{\mathrm{x}}$ emissions decrease south of the ITCZ by $50 \%$ whereas they increase by $45 \%$ over North Africa. During DJF continental emissions decrease in general by around $50 \%$. Oceanic emissions increase by a factor of 2.9 .

\subsubsection{Heterogeneous chemistry}

The original simulation used a reaction probability $\gamma$ of $\mathrm{HO}_{2}$ on all aerosols equal to 0.2 . Laboratory measurements by Thornton et al. (2005) demonstrated that $\mathrm{HO}_{2}$ uptake on aerosols is negligible at temperatures warmer than $270 \mathrm{~K}$ in the absence of $\mathrm{Cu}$ or $\mathrm{Fe}$ ions that would catalyze the reaction. Field measurements of biomass burning aerosol (Yama- 

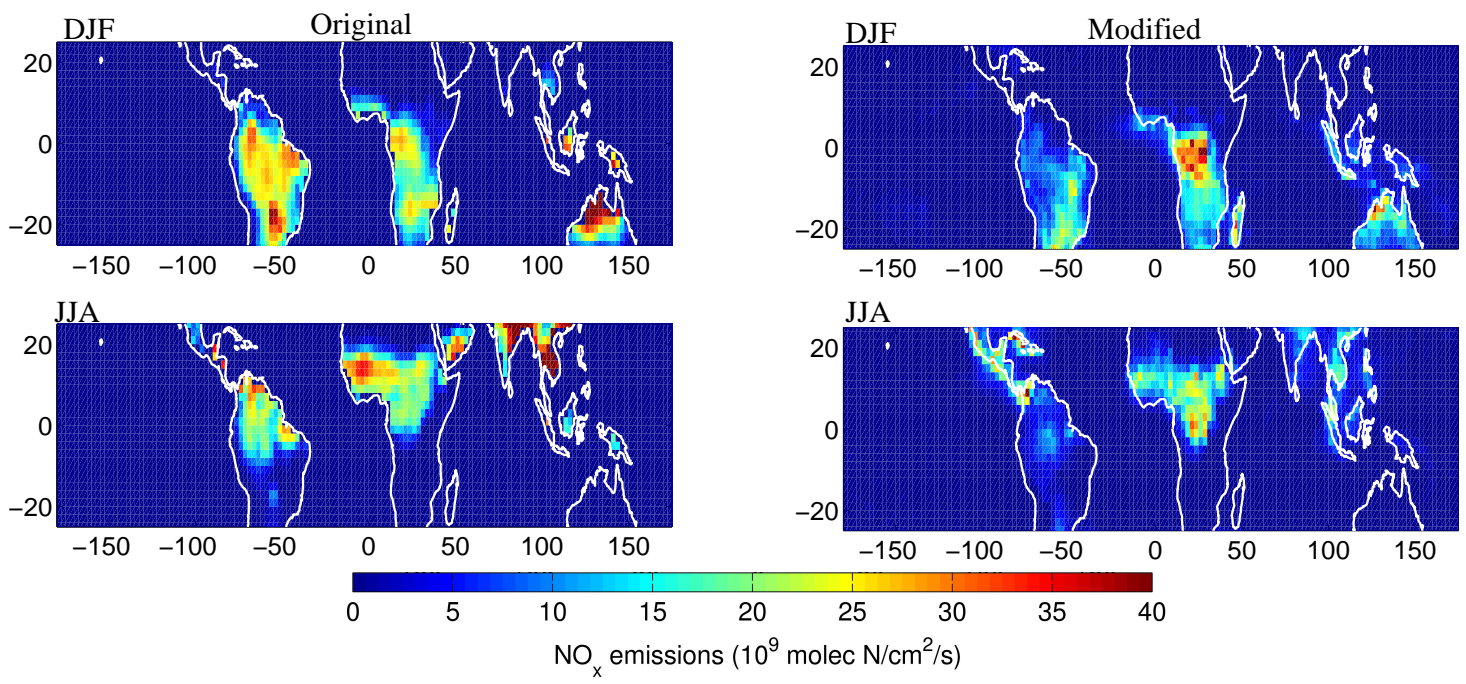

Fig. 3. Seasonal average lightning emissions $\left(10^{9} \mathrm{molec} \mathrm{N} / \mathrm{cm}^{2} / \mathrm{s}\right)$. The left panels show lightning emissions calculated from GEOS dynamics in the original version. The right panels show lightning emissions scaled to OTD/LIS measurements of flash rates as used in the modified simulation.

soe et al., 2000) found insufficient $\mathrm{Cu}$ or Fe ions to catalyze that reaction. We exclude this reaction for biomass burning aerosols.

Following Bauer et al. (2004) we implement $\mathrm{HNO}_{3}$ uptake on mineral aerosols in the modified simulation using $\gamma\left(\mathrm{HNO}_{3}\right)=0.1$. Laboratory experiments have shown that $\mathrm{HNO}_{3}$ uptake on mineral dust is promoted by its alkalinity (Goodman et al., 2000; Grassian, 2000; Underwood et al., 2001; Michel et al., 2002; Hanisch and Crowley, 2003). Field measurements also support $\mathrm{HNO}_{3}$ uptake (Tabazadeh et al., 1998; Thakur et al., 1999). Rapid sedimentation of nitrate on mineral dust could reduce recycling of $\mathrm{NO}_{\mathrm{x}}$ from $\mathrm{HNO}_{3}$, and in turn $\mathrm{O}_{3}$, with lower tropospheric $\mathrm{O}_{3}$ decreases of $8-30 \%$ over and downwind of deserts (Bian et al., 2003; Bauer et al., 2004; Umann et al., 2005; Liao et al., 2005).

There have been few comparisons with in situ measurements to evaluate these heterogeneous processes. In Sect. 4.3 we perform sensitivity studies to evaluate the uptake of $\mathrm{HO}_{2}$ on biomass burning aerosols and uptake of $\mathrm{HNO}_{3}$ on mineral dust.

\section{Assessment of the dynamical and chemical processes affecting tropical tropospheric ozone}

Of particular interest is 1 . the ability of the model to accurately simulate the distribution of tropospheric ozone and its precursors in order to 2 . accurately understand what controls tropical tropospheric ozone. We first give an overview of the distribution of tropospheric ozone columns. We then discuss the processes affecting its distribution in the context of the
MOZAIC and SHADOZ vertical $\mathrm{O}_{3}$ profiles, as well as the GOME tropospheric $\mathrm{NO}_{2}$ and $\mathrm{HCHO}$ columns.

Figure 4 shows seasonal tropospheric ozone columns (TOC) from GOME observations (left) and our modified simulation (middle). TOC are calculated as the integral from the surface to the GEOS-Chem thermal tropopause. The simulated and retrieved $\mathrm{O}_{3}$ columns exhibit similar spatiotemporal variation over the Tropics (monthly $r^{2}=0.91-0.98$; seasonal bias $=1.4-4.4 \mathrm{DU})$. Both show enhancements in the downwelling branches of the Hadley circulation, smaller values in the Tropics, and a zonal wave-one pattern, with maximum TOC between $40 \mathrm{~W}-60 \mathrm{E}$. The original and retrieved TOC are less consistent (monthly $r^{2}=0.67-0.87$ ) although the tropical mean bias remains unchanged.

The right panels show large regional changes of $5 \mathrm{DU}$ in the simulated $\mathrm{O}_{3}$. In the following sections we focus on the consequences of our developments on the comparison of the model versus observations.

\subsection{Sensitivity to lightning}

Here we discuss how the local rescaling of lightning flashes affects the comparison with $\mathrm{O}_{3}$ observations. Then we discuss the sensitivity of the simulation to lightning intensity and to lightning vertical distribution.

\subsubsection{Satellite constraint - lightning rescaling}

As demonstrated below, the local rescaling of lightning flashes to match OTD/LIS measurements yields substantial improvement in the modeled versus observed ozone. We first compare the original and modified simulations at MOZAIC 

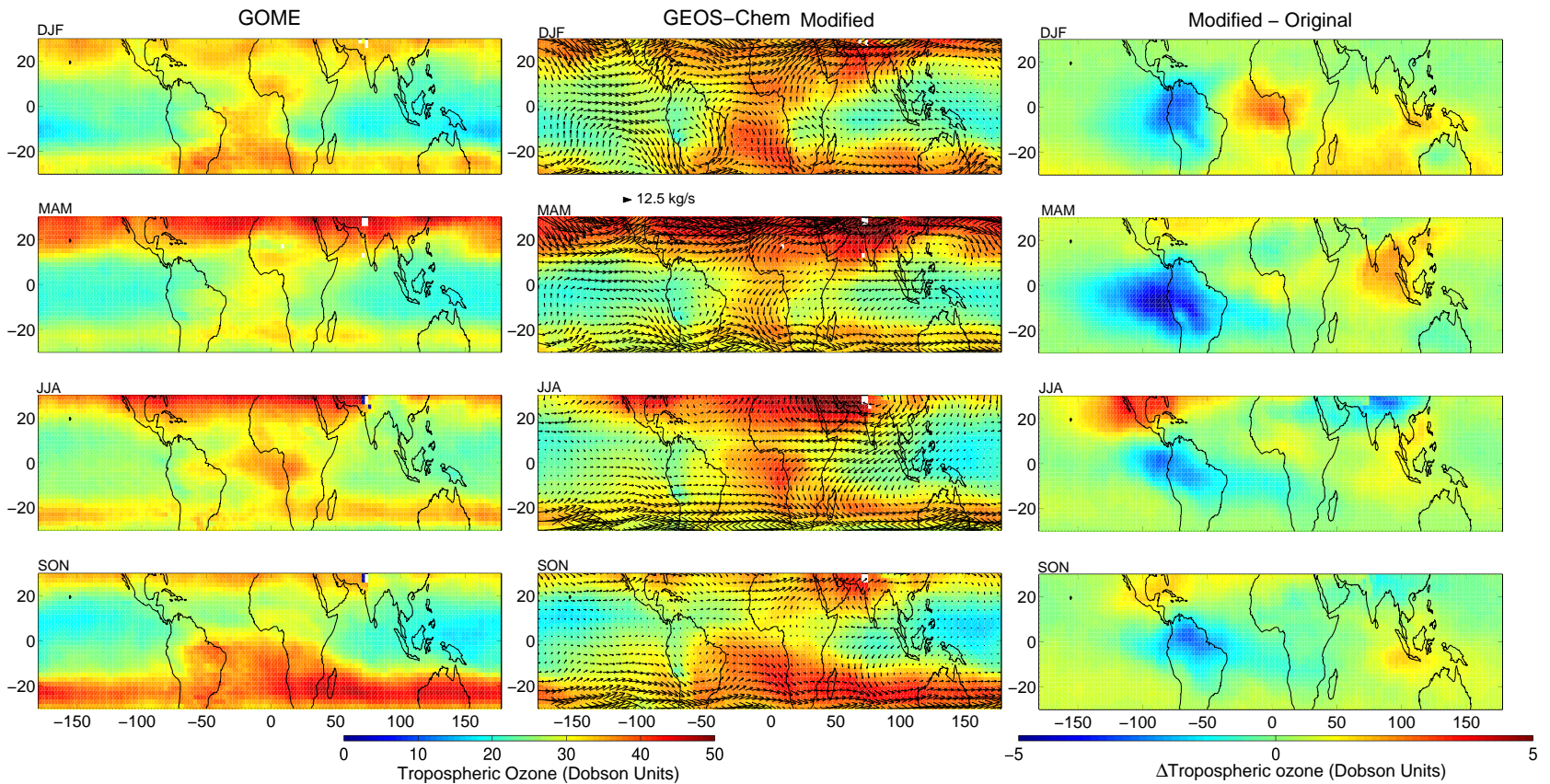

Fig. 4. Seasonal average (left) GOME and (middle) GEOS-Chem (convolved with GOME averaging kernels) tropospheric ozone columns for 2000. The right column represents the difference between the modified and original simulation of tropospheric ozone columns (TOC). The arrows in the middle column represent the horizontal ozone flux integrated from the surface to the tropopause.

and SHADOZ sites that exhibit the largest sensitivity to lightning. These sites are generally in subsidence regions downwind of lightning activity, allowing for $\mathrm{O}_{3}$ production during transport. Figure 5 shows the seasonal $\mathrm{O}_{3}$ vertical profiles for the in situ measurements (MOZAIC, SHADOZ, black lines); the original simulation (blue line), and the modified simulation (red line). Both simulations are generally within one standard deviation of the in situ measurements. However improvements due to the lightning rescaling are apparent in the modified simulation in the middle and upper troposphere.

The first page of Fig. 5 shows continental sites with $\mathrm{O}_{3}$ concentrations of 40-50 ppbv throughout the year in the middle and upper troposphere, sustained by $\mathrm{L}-\mathrm{NO}_{\mathrm{x}}$ emissions in the South American Convergence Zone (SACZ) or the ITCZ. The lightning rescaling reduces $\mathrm{L}^{-\mathrm{NO}_{\mathrm{x}}}$ emissions in South America (Fig. 3) decreasing upper tropospheric $\mathrm{O}_{3}$ during DJF and MAM by 5-10 ppbv over Sao Paolo and by 1015 ppbv over Caracas. The Middle East is frequently under the influence of an anticyclonic circulation in the middle and upper troposphere (Hoskins and Rodwell, 1995) and of easterly flow through the Tropical Easterly jet in the upper troposphere, which brings lightning outflow during the Indian monsoon (Li et al., 2001), mainly during JJA as depicted by the easterly ozone flux (Fig. 4). Reductions in Indian L-NO emissions improve the simulation at Dubai by $5-10 \mathrm{ppbv}$ in JJA and SON. Bangkok is influenced by lightning mostly during the dry season from November to May when the circulation is convergent. Here lightning rescaling improves the
$\mathrm{O}_{3}$ simulation by $5-15 \mathrm{ppbv}$. Other continental sites exhibit less sensitivity due to their proximity to $\mathrm{L}^{-\mathrm{NO}_{\mathrm{x}}}$ emissions.

The effect of local lightning rescaling is also apparent in the TOC. Table 3 contains the TOC for the modified simulation, the in situ measurements, and the GOME retrievals. Lightning rescaling has a considerable effect on $\mathrm{O}_{3}$ over South America (Fig. 4, right panel) reducing the model bias versus the in situ measurements to within 2 DU over Caracas and within 4 DU over Sao Paolo, compared to a difference of more than $8 \mathrm{DU}$ in the original simulation. The simulation is closer to in situ TOC than to GOME observations over both regions. Over the Middle East, lightning rescaling improves the simulated TOC by $3-5$ DU to within $2-5$ DU. The remaining bias at Dubai arises from the $\mathrm{O}_{3}$ overestimate below $600 \mathrm{hPa}$ (Fig. 5). GOME measurements are within $2 \mathrm{DU}$ of the MOZAIC TOC except during DJF when there is a 5 DU underestimate that probably originates from the lower troposphere as noted by Liu et al. (2006). Over South East Asia there is a positive bias of GEOS-Chem TOC of 4 to 7 DU compared to GOME. The lightning rescaling clearly yields better modeled TOC versus MOZAIC to within 1$4 \mathrm{DU}$, compared with $7 \mathrm{DU}$ for the original simulation.

The second panel of Fig. 5 show that lightning rescaling also yields improvements over oceanic sites. Lightning rescaling increases emissions over the South Pacific Convergence Zone (Fig. 3) especially in DJF and SON resulting in a 5-10 ppbv increase in $\mathrm{O}_{3}$ in the middle and upper troposphere (Samoa, Fig. 5). Over Reunion Island there 

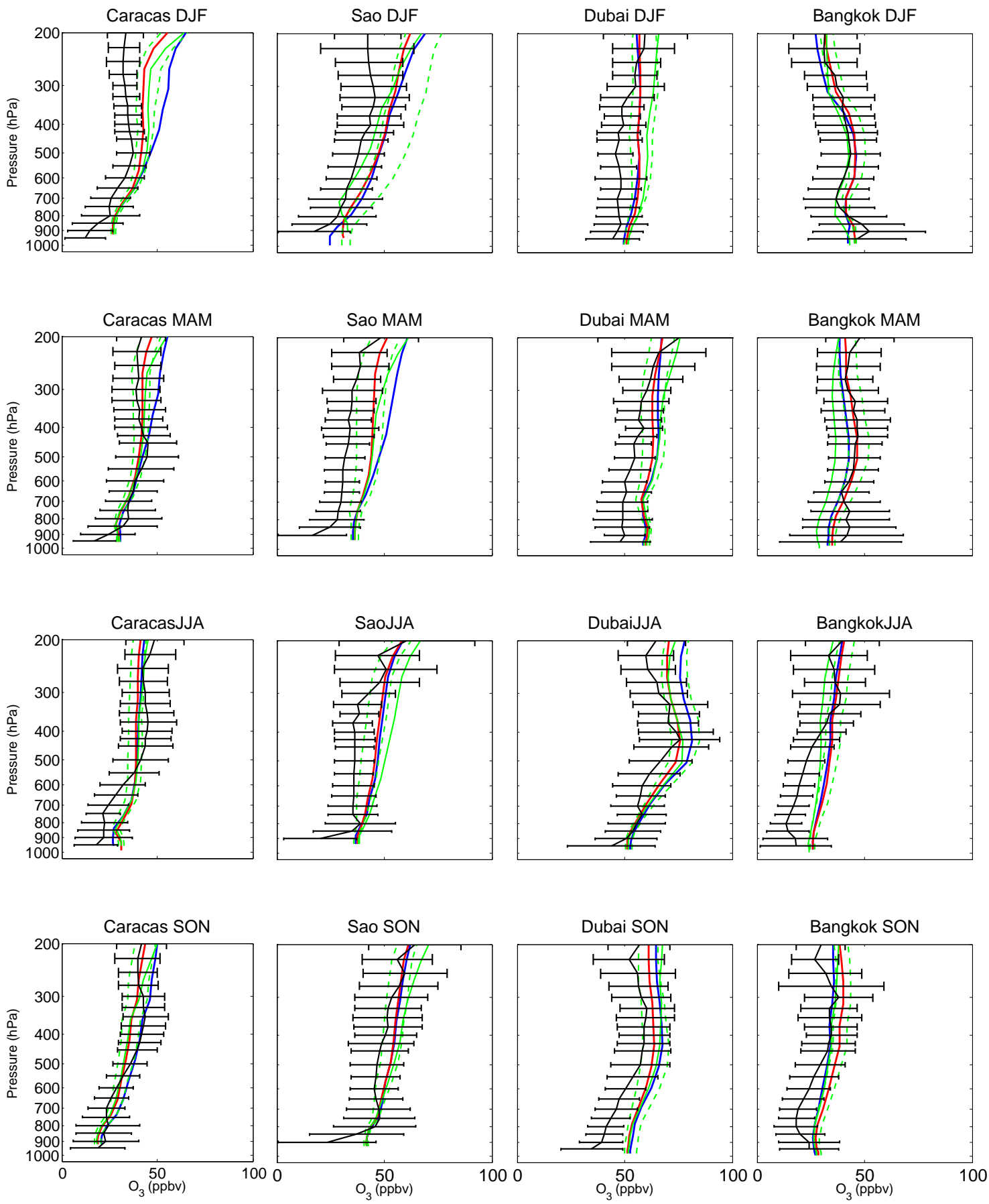

Fig. 5. Seasonal vertical profiles of $\mathrm{O}_{3}$ in ppbv. The black line indicates MOZAIC and SHADOZ measurements of $\mathrm{O}_{3}$. Horizontal bars represent one standard deviation of measurements. $\mathrm{O}_{3}$ simulations are in blue (original) and red (modified). The solid green line indicates a simulation with enhanced intracloud $\mathrm{NO}_{\mathrm{x}}$ emissions. The dashed green lines are from a simulation with $\mathrm{L}-\mathrm{NO}_{\mathrm{x}}$ emissions of $4 \mathrm{TgN} / \mathrm{yr}$ and $8 \mathrm{TgN} / \mathrm{yr}$.

is improvement in DJF due to a $7 \mathrm{ppbv}$ increase in $\mathrm{O}_{3}$. Over the Atlantic, Ascension and Natal depict similar $\mathrm{O}_{3}$ vertical profiles near the maximum of the zonal-wave one, with enhanced mid-upper tropospheric $\mathrm{O}_{3}$ throughout the year. Lightning is a significant source of this enhancement (Thompson et al., 2000; Martin et al., 2002a; Sauvage et al., 2007b). The main improvements are in DJF and MAM with $\mathrm{O}_{3}$ increases of 7-10 ppbv from more lightning over Central 

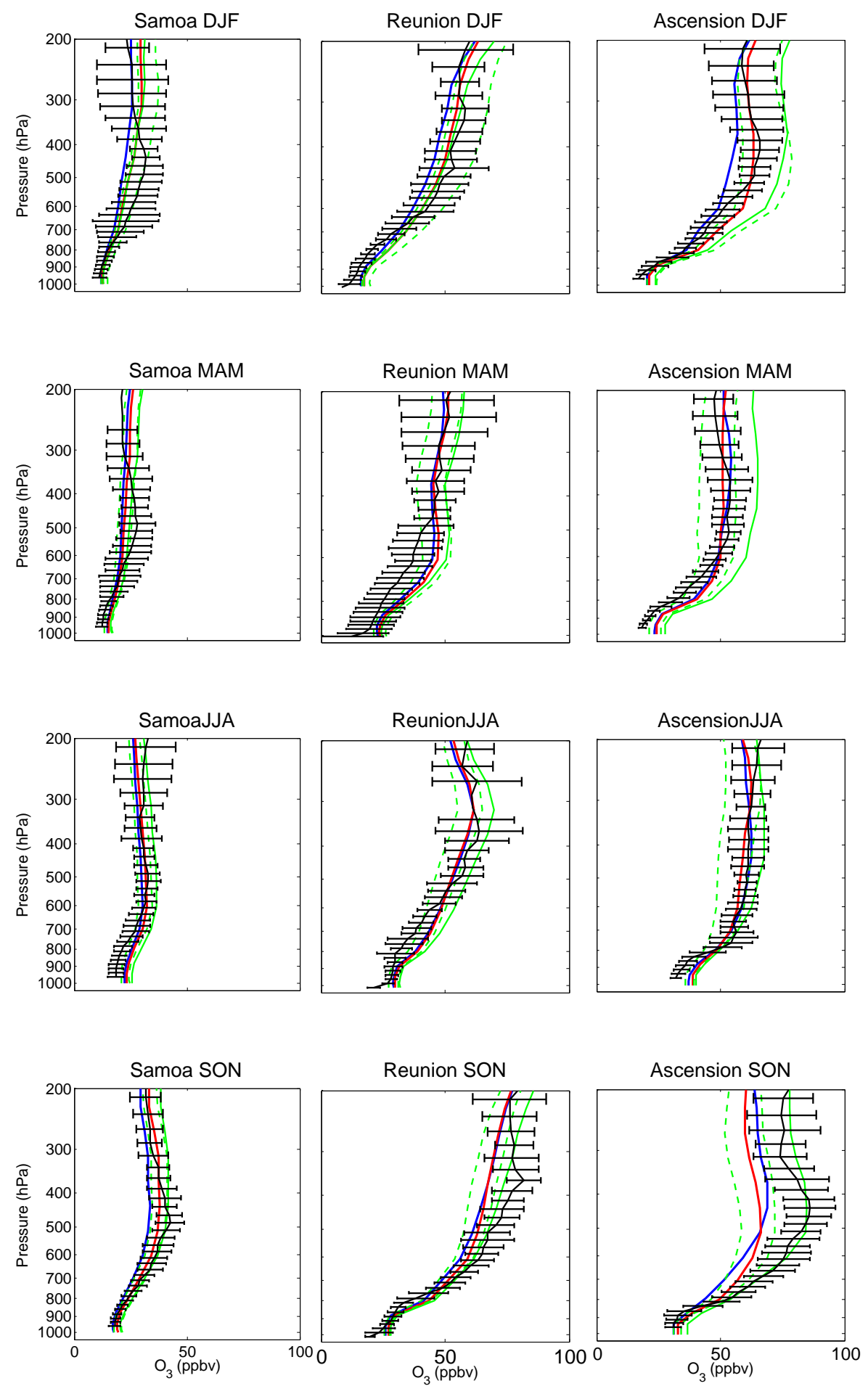

Fig. 5. Continued.

Africa in the modified simulation (Fig. 3). During SON, both simulations in the middle troposphere and upper troposphere underestimate $\mathrm{O}_{3}$ by $10-20$ ppbv, but $\mathrm{O}_{3}$ remains maximum during that season (Thompson et al., 2003b). In the follow- ing Sects. 4.1.2b and 4.4, we discuss possible reasons of this remaining local bias. 
Table 3. Seasonal tropospheric $\mathrm{O}_{3}$ column (DU) from the GEOS-Chem modified simulation (difference with original simulation is given in parenthesis)/MOZAIC or SHADOZ (standard deviation $1 \sigma$ is in parenthesis)/and GOME. For MOZAIC we complete the column between the aircraft ceiling of $185 \mathrm{hPa}$ and the tropopause with a fixed ozone mixing ratio of $70 \mathrm{ppbv}$.

\begin{tabular}{lcccc}
\hline \multicolumn{5}{c}{ GEOS-Chem/MOZAIC-SHADOZ/GOME TOC } \\
\hline Regions & DJF & MAM & JJA & SON \\
\hline Caracas & $26.6(-4.2) / 22.2(3.2) / 27$ & $29.6(-3.1) / 28.8(4.5) / 26.9$ & $27.6(-1.8) / 26.3(4) / 27.9$ & $25.3(-2.5) / 25.2(3.8) / 25.8$ \\
Sao Paolo & $32.7(-0.5) / 29.4(4.6) / 35.4$ & $29.4(-4.1) / 24.7(3.2) / 32$ & $30.1(-0.2) / 29.4(4.1) / 29.5$ & $37.4(-0.6) / 34.7(5) / 39$ \\
Dubai & $40(+0.1) / 38.8(3.6) / 34$ & $43.9(-1.7) / 41.6(4.5) / 44.5$ & $50.1(-2.7) / 45.2(4.7) / 43.5$ & $40.9(-2.2) / 36(3.6) / 35$ \\
Samoa & $17.4(+1.8) / 18.4(3.2) / 16.4$ & $19(+0.9) / 17.9(5) / 19.5$ & $20.4(+1) / 20.2(4) / 24.4$ & $22.1(+3.2) / 23(5) / 23$ \\
Reunion & $32.6(+2.2) / 32.4(4.5) / 30$ & $31(+1) / 32(6) / 31.5$ & $34.1(+0.4) / 34.7(5) / 33$ & $43.4(+1.1) / 45.2(5) / 45$ \\
Ascension & $36(+3.2) / 35.4(5) / 32.8$ & $31(-1) / 30.9(5) / 30.5$ & $38.2(-0.6) / 40.6(6.2) / 34.5$ & $40.7(-0.9) / 44(6.4) / 37.7$ \\
Natal & $34.3(+2.5) / 34.2(4.5) / 33.5$ & $27.2(-1.2) / 26(5) / 29.4$ & $33.8(-0.4) / 36.2(4.2) / 32.73$ & $37.3(-0.7) / 41(6) / 37.4$ \\
Lagos & $40.1(+5.9) / 40.5(3.9) / 34$ & $36(+2.7) / 37.5(2.2) / 32.5$ & $32.5(+2.4) / 33(3.2) / 31$ & $32(-0.1) / 32.5(2.6) / 29.5$ \\
Brazzaville & $34.5(+4.8) / 36.7(3.3) / 29.5$ & $31.5(+2) / 32.5(3.4) / 29.4$ & $48.8(+6.3) / 49(3.6) / 37.5$ & $40.3(+1) / 43(2.8) / 34.7$ \\
Windhoek & $32.8(+0.9) / 31.5(2.6) / 32$ & $29.3(-0.1) / 28.7(3.1) / 29.7$ & $33.3(+0) / 32.4(3.2) / 33.1$ & $41.2(+1.2) / 42.1(3.4) / 42.1$ \\
Bombay & $40.7(+0.4) / 40.1(5) / 33.3$ & $41.6(-2.5) / 40.3(4) / 35.5$ & $34.9(-2.1) / 30.3(5.4) / 28.6$ & $36.1(+1.1) / 35.6(4.1) / 31.7$ \\
Average & $31.8 / 32.7(3.9) / 30.7$ & $31.7 / 30.9(4.1) / 31$ & $34.8 / 34.3(4.3) / 32.3$ & $36.0 / 36.5(4.3) / 33.9$ \\
\hline
\end{tabular}

The TOC over oceans are generally consistent between the modified simulation, GOME, and in situ measurements, within 5 DU everywhere. Over Ascension the modified simulation is closer than the original one to in situ measurements by 1-3 DU in DJF and MAM. However there is still an underestimate of $4 \mathrm{DU}$ in SON. Better agreement is found over the Pacific and Indian Ocean, within 1-3 DU compared to in situ measurements, and within 2-5 DU versus GOME TOC.

The seasonal cycle of the modeled TOC is reproduced for all sites, except over Caracas. The last line of Table 3 shows that for the TOC averaged for the tropical sites, the three datasets are within $2 \mathrm{DU}$ bias and within $1 \sigma$ of the measurements. The seasonal cycle is well reproduced, with maximum in SON, minimum in MAM, as depicted by the southern hemispheric zonal-wave one pattern (Thompson et al., 2003b; Sauvage et al., 2006).

\subsubsection{Lightning intensity and distribution}

\section{a. Sensitivity to intensity}

In order to evaluate the lightning $\mathrm{NO}_{\mathrm{x}}$ source of $6 \mathrm{Tg}$ $\mathrm{N} / \mathrm{yr}$, we conduct sensitivity studies based on the modified simulation that vary the intensity over $4-8 \mathrm{Tg} \mathrm{N} \mathrm{yr}^{-1}$.

Figure 5 shows the sensitivity of the seasonal $\mathrm{O}_{3}$ verti-

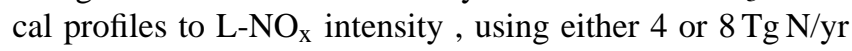
(dashed green lines). Lower concentrations reflect the simulation with $3 \mathrm{TgN} / \mathrm{yr}$. In general $\mathrm{O}_{3}$ is perturbed throughout the entire troposphere by $5-10$ ppbv. The simulation remains nearly within one modified deviation of measurements. However $4 \mathrm{Tg} \mathrm{N} / \mathrm{yr}$ is generally too low. In contrast $8 \mathrm{Tg} \mathrm{N} / \mathrm{yr}$ is generally too high. The largest sensitivity to intensity is found over the Atlantic region where $\mathrm{O}_{3}$ concentrations change by $10-20 \mathrm{ppbv}$. The simulation with $8 \mathrm{Tg} \mathrm{N} / \mathrm{yr}$ reduces the model bias versus in situ measurements in SON at Ascension (Fig. 5), but creates a bias during other seasons, and at most other sites. Emissions of $10.7 \mathrm{Tg}$ N/yr would be necessary to achieve in situ $\mathrm{O}_{3}$ concentrations in $\mathrm{SON}$ at Ascension. Another process is likely responsible for the bias.

In summary, $6 \pm 2 \mathrm{Tg} \mathrm{N} \mathrm{yr}^{-1}$ represents the plausible range of lightning $\mathrm{NO}_{\mathrm{x}}$ emissions. Outside of that range, simulated $\mathrm{O}_{3}$ becomes increasingly inconsistent with in situ measurements. Martin et al. (2007) found a similar magnitude of $6 \pm 2 \mathrm{Tg} \mathrm{N} \mathrm{yr}^{-1}$ best agreed with space-based measurements of $\mathrm{NO}_{2}, \mathrm{O}_{3}$ and $\mathrm{HNO}_{3}$. Schumann and Huntrieser (2007) estimate a comparable magnitude of $5 \pm 3 \mathrm{Tg} \mathrm{N} \mathrm{yr}^{-1}$ in a very thorough review of observations and simulations over the last decades.

\section{b. Sensitivity to distribution}

The vertical distribution of lightning emissions is also important (Labrador et al., 2005). Most previous studies assumed much higher $\mathrm{NO}_{\mathrm{x}}$ emissions per flash for cloud to ground (CG) flashes than intra-cloud (IC) flashes (Price et al., 1997; Pickering et al., 1998). However, recent studies provide evidence that the IC/CG ratio may be between 0.5-1.0 (DeCaria et al., 2000; Fehr et al., 2004). The implications had not yet been evaluated versus tropical in situ $\mathrm{O}_{3}$ data. We explore the implications of increasing the IC/CG ratio to 0.75 , instead of 0.1 in our modified simulation. The additional $\mathrm{NO}_{\mathrm{x}}$ from IC flashes is distributed within the cloud anvil while preserving the global lightning $\mathrm{NO}_{\mathrm{x}}$ rate.

The simulation using enhanced IC emissions is shown in Fig. 5 (solid green line). Generally, this lightning parameterization overestimates middle-upper tropospheric $\mathrm{O}_{3}$, but remains within one modified deviation of measurements. The 

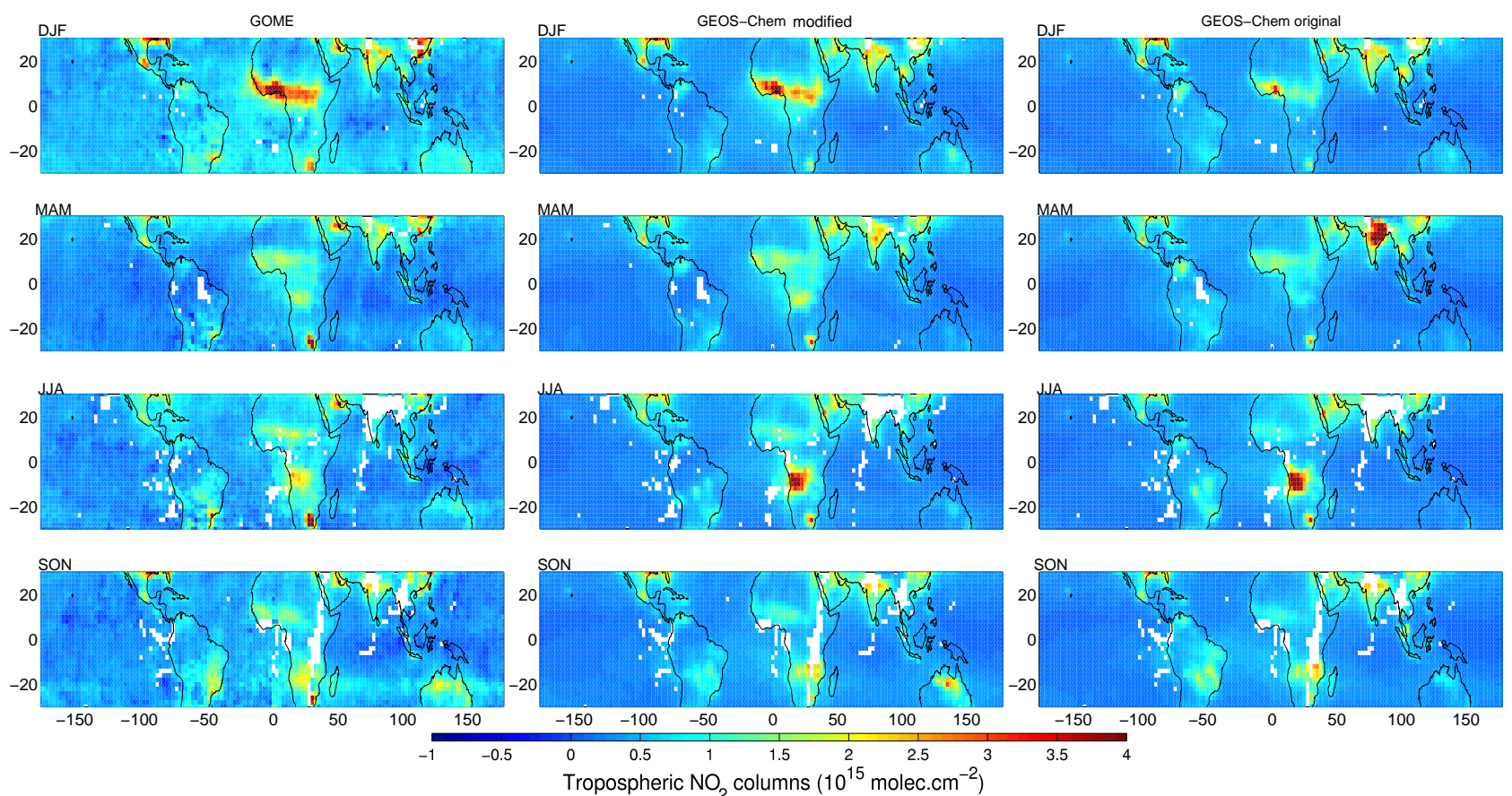

Fig. 6. Seasonal averaged tropospheric $\mathrm{NO}_{2}$ columns $\left(10^{15}\right.$ molec $\left.\mathrm{cm}^{-2}\right)$ during the year 2000. The left panels are for GOME, the middle for GEOS-Chem modified and the right for GEOS-Chem original simulations. White areas indicate regions with persistent clouds.

effects vary with season and location, with for example negligible effect at Caracas, a negative bias at Bangkok, and a large impact at Ascension. Over Ascension, $\mathrm{O}_{3}$ concentrations are biased high in DJF and MAM by 10-15 ppbv, but the model bias in SON is eliminated, suggesting a seasonal variation in the IC/CG ratio. In summary, a uniform increase in the IC/CG ratio is unsupported by the in situ $\mathrm{O}_{3}$ profiles, but it could be higher for particular geographical regions.

\subsection{Sensitivity to biomass burning and soils}

In this section we address the following questions: What are the consequences of the modifications to surface emissions of $\mathrm{NO}_{\mathrm{x}}$ and VOCs on $\mathrm{O}_{3}$ distributions? Do these changes improve the simulated tropospheric $\mathrm{O}_{3}$ compared to in situ measurements?

\subsubsection{Satellite constraint}

Figure 6 shows seasonal average GOME (left) and GEOSChem (middle: modified; right: original) tropospheric columns of $\mathrm{NO}_{2}$, during 2000. The GOME and GEOSChem modified $\mathrm{NO}_{2}$ columns are highly consistent over the Tropics during the 4 seasons. The coefficient of determination of the retrieved columns versus the modified simulation during the 4 seasons $\left(r^{2}=0.8-0.9, p<0.0001\right)$ is higher than versus the original simulation, which are in the range of $r^{2}=0.6-0.8$. Correlations of the retrieved slant columns with the model vertical columns for the modified simulation $\left(r^{2}=0.7-0.8\right)$ and the original simulation $\left(r^{2}=0.6-\right.$ 0.7) confirm that the model shape factors have a minor role on the agreement. The annual mean absolute difference between the modified simulation and retrieved columns over the Tropics is $0.2 \times 10^{15}$ molecules $\mathrm{cm}^{-2}$ compared with $0.7 \times 10^{15}$ molecules $\mathrm{cm}^{-2}$ in the original simulation. The modified simulation better reproduces seasonal $\mathrm{NO}_{2}$ maxima observed by GOME. For instance over Northern Africa during DJF and MAM, top down biomass burning $\mathrm{NO}_{\mathrm{x}}$ emissions enhance lower tropospheric $\mathrm{NO}_{2}$ concentrations by a factor of 2.6, reducing a regional model bias. Over Central Africa, the regional bias in JJA and SON is reduced, however a local bias remains during JJA reflecting the regional emission factor applied here. Over India $\mathrm{NO}_{2}$ tropospheric column are reduced by a factor 4 during the biomass burning season of MAM, better representing GOME columns. During May to July the a posteriori soil $\mathrm{NO}_{\mathrm{x}}$ emission inventory better reproduces the $\mathrm{NO}_{2}$ column enhancement over the Sahel. Further studies should investigate whether top-down inventories for a specific year improve simulations for other years.

Figure 7 shows seasonal average GOME (left) and GEOS-Chem (middle modified; right original) tropospheric columns of HCHO during 2000. The spatio-temporal correlation of the retrieval columns with the modified simulation $\left(r^{2}=0.7-0.9\right)$ is quite high compared with 0.60.75 versus the original simulation. The coefficients of determination for the retrieved slant columns versus 

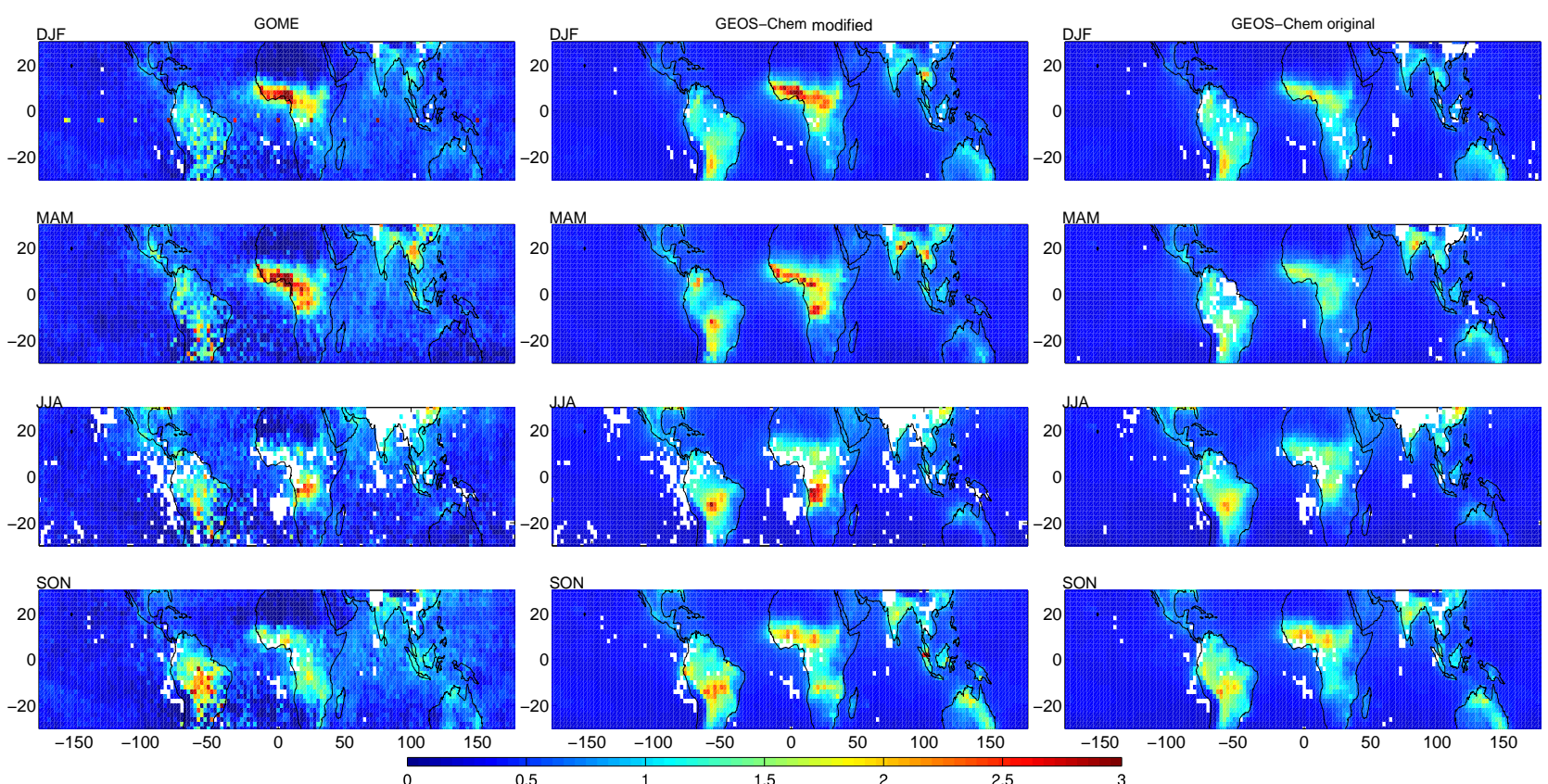

Fig. 7. Seasonal averaged tropospheric HCHO columns $\left(10^{16} \mathrm{molec}^{-2}\right)$. The left panels are for GOME, the middle are for GEOS-Chem modified and the right for GEOS-Chem original. White areas represent persistent clouds.

the model vertical columns are $0.6-0.8$ for the modified simulation and $0.5-0.65$ for the original simulation. The mean absolute difference between GOME and the modified simulation is $0.06 \times 10^{16}$ molecules $\mathrm{cm}^{-2}$, versus $0.2 \times 10^{16}$ molecules $\mathrm{cm}^{-2}$ with the original simulation. Previous regional differences of more than a factor of 2 are reduced during the biomass burning season to $20 \%$ in the modified simulation over Northern Africa in DJF-MAM and to 35\% over Central Africa and South America in JJA-SON. The remaining model biases likely reflect isoprene emissions.

\subsubsection{Evaluation with in situ data}

Figure 8 shows $\mathrm{O}_{3}$ profiles at MOZAIC sites that have the greatest sensitivity to surface emissions. West equatorial (Lagos, Abidjan) and Central Africa (Brazzaville) sites exhibit $\mathrm{O}_{3}$ enhancements related to seasonal biomass burning fires (Fig. 8) driven by the lower tropospheric Harmattan and trade flow. The new CO measurements confirm the sensitivity of those sites to biomass burning (as shown in Fig. 9) and as noted by Edwards et al. (2003) in their analysis of CO retrieved from the MOPITT satellite instrument. During DJF, $\mathrm{O}_{3}$ enhancements in the lower troposphere over West Africa have the highest tropical CO concentrations measured by the MOZAIC program, with 200-500 ppbv at Lagos below $700 \mathrm{hPa}$ (Fig. 9) and 200-400 ppbv below $500 \mathrm{hPa}$ at Douala (not shown). High CO concentrations originating from biomass burning fires over Central Africa are measured near 600-700h Pa over Lagos and Douala during JJA. Trade winds allow this $\mathrm{CO}$ transport and the associated $\mathrm{O}_{3}$ enhancement (Sauvage et al., 2005). Aghedo et al. (2006) also found a high influence of biomass burning on surface $\mathrm{O}_{3}$. A persistent $\mathrm{CO}$ enhancement that may reflect local pollution is observed at Delhi, with more than $150 \mathrm{ppbv}$ below $800 \mathrm{hPa}$. No CO measurements are performed south of the ITCZ.

As a result of the GOME constraints on surface emissions, the simulation better reproduces lower tropospheric $\mathrm{O}_{3}$. During DJF over Lagos and Abidjan, the intensity of the lower tropospheric $\mathrm{O}_{3}$ enhancement is now well reproduced mostly because of the higher $\mathrm{NO}_{\mathrm{x}}$ emission factors that increase $\mathrm{O}_{3}$ by $15-20 \mathrm{ppbv}(+45 \%)$ compared to the original version. Five ppbv of the 15-20 ppbv increase are attributed to the additional biomass burning VOCs. Moreover, Brazzaville shows an $\mathrm{O}_{3}$ enhancement in the lower troposphere through inter-hemispheric transport $(+15 / 20 \mathrm{ppbv}(+55 \%)$ compared to the original version).

During JJA over Brazzaville the intensity of the $\mathrm{O}_{3}$ maximum is also better reproduced (+10 ppbv/ $+14 \%)$, as a consequence of both the higher $\mathrm{NO}_{\mathrm{x}}$ and VOC emissions. These emissions also yield a better reproduction of the $\mathrm{O}_{3}$ enhancement at Lagos through inter hemispheric transport. The enhancement near $600-700 \mathrm{hPa}$ is also increased by $7 \mathrm{ppbv}$ due to the a posteriori soil $\mathrm{NO}_{\mathrm{x}}$ emissions. 

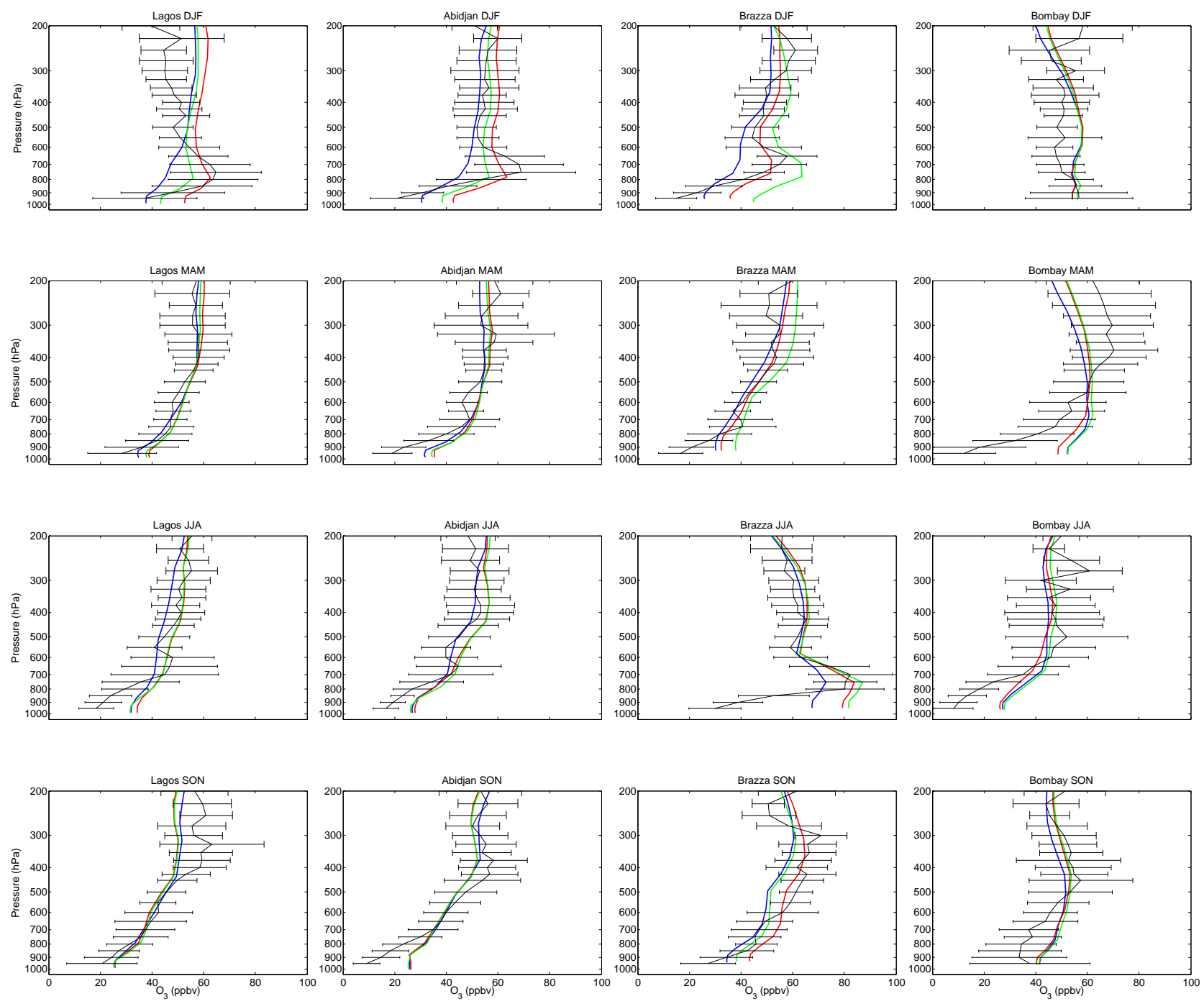

Fig. 8. Seasonal vertical profiles of $\mathrm{O}_{3}$ in ppbv. The plain black line indicates in situ $\mathrm{O}_{3}$. Horizontal bars represent one standard deviation of the measurements. $\mathrm{O}_{3}$ simulations are in blue (original), red (modified), and in green for in-situ-based on $\mathrm{NO}_{\mathrm{x}}$ emission factors.

There are improvements associated with biomass burning emissions over the South American Cerrado in SON, and over India in MAM. $\mathrm{O}_{3}$ decreases in the lower troposphere of Bombay by around 5-7 ppbv (8-10\%). However $\mathrm{O}_{3}$ is still too high in the lower troposphere, perhaps reflecting a combination of local sea breeze not resolved at the coarse resolution of the model, missing halogen chemistry (Dickerson et al., 1999; Stehr et al., 2002), or inefficient $\mathrm{O}_{3}$ production in urban areas (Dickerson et al., 2002).

The top-down emissions also affect the TOC (Table 3). Over the Gulf of Guinea (Lagos) the modified simulation is within 1 DU of MOZAIC versus 6 DU for the original simulation. Over Central Africa the modified simulation is within $2 \mathrm{DU}$ versus MOZAIC during DJF compared to $6 \mathrm{DU}$ in the original simulation. The seasonal cycle is well reproduced, with maximum during JJA and minimum during MAM over
Central Africa, maximum during DJF and minimum during JJA over West Africa. Over Windhoek the bias is within 1$2 \mathrm{DU}$ for all the seasons. Over India modeled TOC is within 1-5 DU of MOZAIC during all seasons except JJA, reflecting the lower tropospheric bias.

Comparisons between GOME and GEOS-Chem TOC also show substantial improvements. Most of the differences between GOME and the modified GEOS-Chem TOC are within 3 DU. The largest differences appear in the northern tropics, with a negative bias of 5 to 8 DU between GOME and GEOSChem. Table 3 shows that the GOME TOC underestimate MOZAIC in this region, perhaps reflecting the low sensitivity of GOME to lower tropospheric $\mathrm{O}_{3}$, especially in the presence of aerosols from biomass burning or mineral dust. A retrieval of tropospheric $\mathrm{O}_{3}$ using the scan-angle method better captures lower tropospheric $\mathrm{O}_{3}$ and seasonal TOC variation 

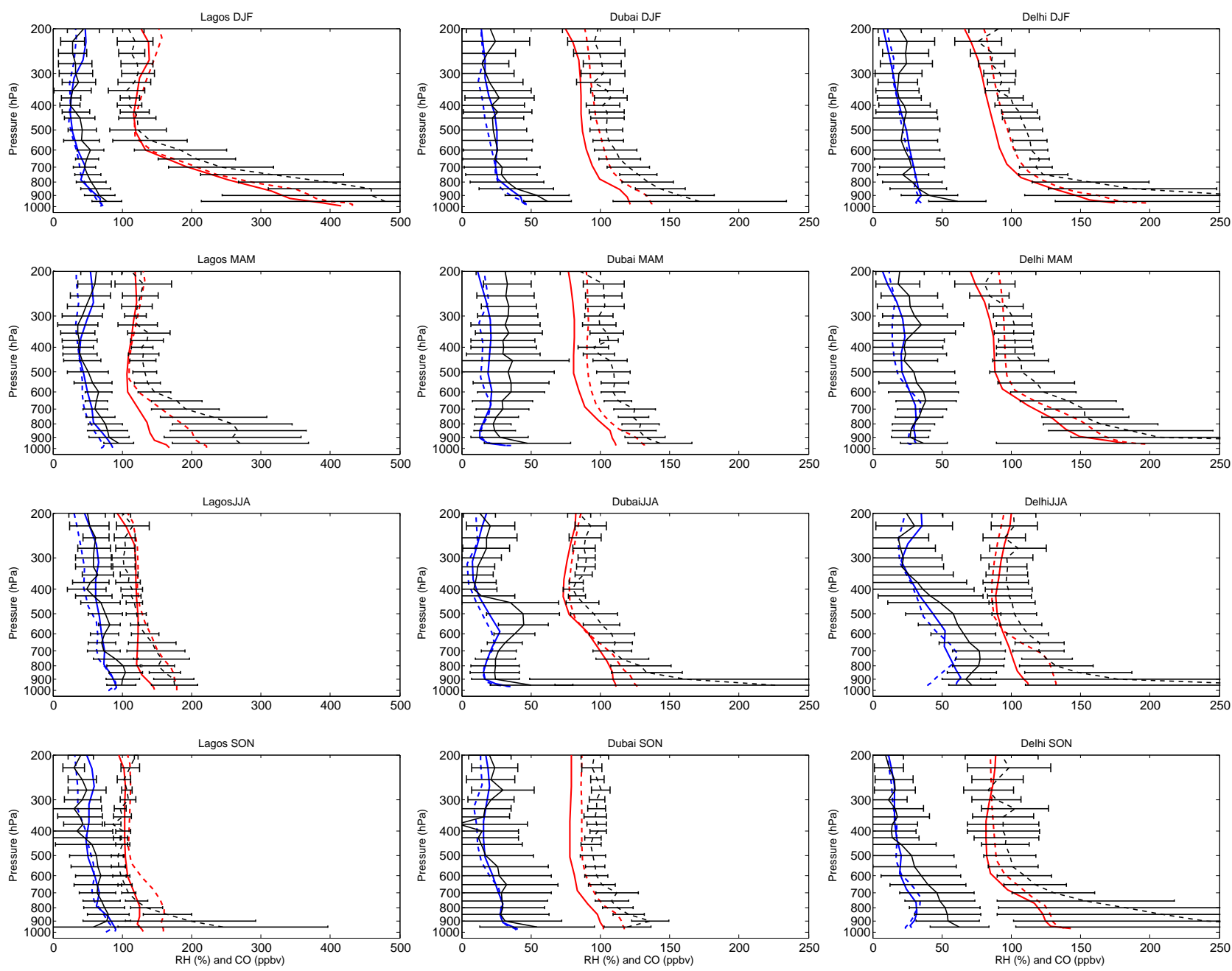

Fig. 9. Seasonal vertical profiles of relative humidity (RH) and CO. Black solid lines are for MOZAIC RH. Black dashed lines are for MOZAIC CO. GEOS-4 simulations are in solid lines, GEOS-3 in dashed lines, with blue for RH and red for CO.

by exploiting the difference in retrieval information between nadir and high viewing angles (Kim et al., 2005). Instrument sensitivity may also play a role over Central Africa during JJA, when GOME TOC biased low by 10 DU compared to MOZAIC at Brazzaville.

\subsubsection{Biomass burning emission factors}

We compare the modified simulation with a sensitivity simulation using a recent compilation of biomass burning emission factors (EF) from Andreae (Andreae and Merlet, 2001; Andreae, personal communication, 2005), that were compiled from in situ measurements. The main differences versus the original simulation are a $23 \%$ lower $\mathrm{NO}_{\mathrm{x}} \mathrm{EF}$ for savannas/grassland and a $15 \%$ higher $\mathrm{NO}_{\mathrm{x}} \mathrm{EF}$ for tropical forest fires. The new EF for savanna and grassland also feature $100 \%$ higher values for $\mathrm{HCHO}$ and $200 \%$ for alkenes.
The green line in Fig. 8 shows the $\mathrm{O}_{3}$ simulation using the in-situ-based emission factors. The in-situ-based emission factors reduce the original bias versus $\mathrm{O}_{3}$ over West Africa but still yield insufficient $\mathrm{O}_{3}$ in contrast with the top-down emissions. Over Central and South Africa, in-situ-based emission factors increase $\mathrm{O}_{3}$ by $10-15 \mathrm{ppbv}$ in JJA with respect to the original simulation, $5 \mathrm{ppbv}$ more than the modified simulation. During DJF $\mathrm{O}_{3}$ is $20 \mathrm{ppbv}$ higher than the modified simulation. Over India during the biomass burning season, the new emission factors have no effect on the lower tropospheric $\mathrm{O}_{3}$ distribution, in contrast with the space-based constraint, which decreases $\mathrm{O}_{3}$ by 5 ppbv yielding a simulation more consistent with in situ measurements. The amount of biomass burned may be responsible for the bias in the original simulation for India as evident from a similar bias in $\mathrm{CO}$ (Heald et al., 2003). 
In summary the recent compilation has similarities with the top-down emissions, but less successfully reproduces $\mathrm{O}_{3}$ observations. We go on to infer regional $\mathrm{NO}_{\mathrm{x}}$ and VOC emission factors from the top-down inventory over Africa and the bottom-up estimate of biomass burned. The resulting emission factors for savanna/grassland fires are $2.9 \mathrm{~g} \mathrm{NO} / \mathrm{kg}$ over North Africa, $4.3 \mathrm{~g} \mathrm{NO} / \mathrm{kg}$ over Central/South Africa and $3.1 \mathrm{~g} \mathrm{NO} / \mathrm{kg}$ over the South American Cerrado. This leads to $3.4 \mathrm{~g} \mathrm{NO} / \mathrm{kg}$ mean for savanna/grassland, at the upper limit of the recommendation from Andreae (Andreae and Merlet, 2001; Andreae, personal communication, 2005) with $2.3 \pm 1.1 \mathrm{~g} \mathrm{NO} / \mathrm{kg}$. For tropical forest fires the top-down $\mathrm{EF}$ are $2.3 \mathrm{~g} \mathrm{NO} / \mathrm{kg}$ over North Africa, $2.6 \mathrm{~g} \mathrm{NO} / \mathrm{kg}$ over Central/South Africa and $2.0 \mathrm{~g} \mathrm{NO} / \mathrm{kg}$ over South America leading to $2.3 \mathrm{~g} \mathrm{NO} / \mathrm{kg}$ mean versus $1.8 \pm 0.7$ from Andreae (Andreae and Merlet, 2001; Andreae, personal communication, 2005).

The resulting emission factors for savanna/grassland fires are $0.96 \mathrm{~g} / \mathrm{kg}$ for alkenes, and $0.7 \mathrm{~g} / \mathrm{kg}$ for $\mathrm{HCHO}$ close to the recommendation by Andreae (Andreae and Merlet, 2001; Andreae, personal communication, 2005) with $1.1 \pm 0.6 \mathrm{~g} / \mathrm{kg}$ and $0.7 \pm 0.4 \mathrm{~g} / \mathrm{kg}$ for $\mathrm{HCHO}$.

\subsubsection{Sensitivity to biogenic emissions}

We explore whether the HCHO bias in the original simulation could be related to isoprene emissions by conducting a sensitivity simulation using the recent Model Emissions of Gases and Aerosols from Nature (MEGAN) inventory (Guenther et al., 2006). This inventory yields $600 \mathrm{Tg} \mathrm{C} / \mathrm{yr}$ of isoprene emissions and has improved the HCHO simulation over the United States (Palmer et al., 2006). However the simulation using MEGAN (not shown) increases HCHO columns over the Amazonian and Equatorial African forest, for all seasons. The general effect is to introduce an overestimate of the tropospheric $\mathrm{HCHO}$ columns outside of the wet and biomass burning seasons. Moreover the MEGAN inventory generally decreases $\mathrm{O}_{3}$ in the lower and middle troposphere by 3-5 ppbv, reducing agreement with in situ $\mathrm{O}_{3}$ data. In summary there is a higher consistency in the comparison of GOME vs. the GEOS-Chem modified simulation than in the comparison of GOME vs. the GEOS-Chem simulation using MEGAN, supporting the previous conclusion of an underestimate of biomass burning VOCs in the bottom-up emission inventory.

\subsection{Sensitivity to heterogeneous chemistry}

Here we examine the implications of the heterogeneous chemistry updates described in Sect. 3.2.4, specifically the neglect of $\mathrm{HO}_{2}$ uptake on biomass burning aerosols, and the uptake of $\mathrm{HNO}_{3}$ on mineral dust. We also explore the effect of direct $\mathrm{O}_{3}$ destruction on mineral dust. This section provides a first overall evaluation of these processes, through comparison with in situ $\mathrm{O}_{3}$ measurements over a broad area.
The exclusion of $\mathrm{HO}_{2}$ uptake on biomass burning aerosols in our modified simulation systematically increases modeled $\mathrm{O}_{3}$ over biomass burning regions by $5-7$ ppbv, improving the consistency with in situ measurements as shown in Fig. 8. Elsewhere no effect is found over the Tropics.

Figure 10 shows vertical profiles of $\mathrm{O}_{3}$ at locations and seasons in which $\mathrm{HNO}_{3}$ uptake had a large effect. As found by Bauer et al. (2004) heterogeneous uptake of $\mathrm{HNO}_{3}$ reduces $\mathrm{O}_{3}$ primarily over and downwind of deserts, i.e. northern Africa and South America, the Arabic peninsula, and India. We find that the reduction in $\mathrm{O}_{3}$ reduces model biases compared to in situ measurements. There is significant improvement over Dubai and Bombay during March to November, when $\mathrm{O}_{3}$ is reduced by $10-15 \%$. The simulated $\mathrm{O}_{3}$ column enhancement over the Middle East is reduced by this process. Over Caracas, there is a $3-5$ ppbv (10\%) $\mathrm{O}_{3}$ decrease below $800 \mathrm{hPa}$ from November to August, when there is a long range transport from the Sahara. Over Lagos $\mathrm{HNO}_{3}$ uptake reduces $\mathrm{O}_{3}$ by a maximum of $5 \%$.

The uptake of $\mathrm{HNO}_{3}$ on mineral dust implemented here, using a reaction probability formulation for convenience, likely represents an upper limit. The particle alkalinity would likely be consumed during continued exposure to $\mathrm{HNO}_{3}$ and $\mathrm{H}_{2} \mathrm{SO}_{4}$ and would be better represented in an equilibrium partitioning. Aerosol nitrate could photolyze to regenerate $\mathrm{NO}_{\mathrm{x}}$ (Anastasio and Mc Gregor , 2001). Nonetheless, we find observational evidence in support of the reaction.

We also explored the effect of direct $\mathrm{O}_{3}$ destruction on mineral dust using $\gamma\left(\mathrm{O}_{3}\right)=10^{-5}$ as recommended from recently laboratory measurements by Hanisch and Crowley (2003). The effect of this reaction on $\mathrm{O}_{3}$ is smaller than that of $\mathrm{HNO}_{3}$ uptake as found by Bauer et al. (2004). However $\mathrm{O}_{3}$ uptake had a large negative role over Lagos during DJF in the lower troposphere, leading to a $15-20 \%$ reduction of the $\mathrm{O}_{3}$ biomass burning enhancement.

In summary, $\mathrm{HNO}_{3}$ uptake on mineral dust and the exclusion of $\mathrm{HO}_{2}$ uptake on biomass burning aerosols improves the simulation versus MOZAIC and SHADOZ sites. This is not the case for $\mathrm{O}_{3}$ uptake, which had no effect over the Middle East and India, and a negative effect over West Africa.

\subsection{Sensitivity to dynamics}

In this section we compare the effect on chemical species of two different assimilated meteorological datasets provided by the Goddard Earth Observing System data assimilation system at the NASA Global Modeling and Assimilation office: GEOS-3 and GEOS-4. GEOS-3 uses the Relaxed Arakawa Schubert (Moorthi and Suarez , 1992) convective parameterization. GEOS-4 uses the Zhang and McFarlane (1995) parameterization for deep convection and the Hack (1994) parameterization for shallow convection. The major differences between GEOS-3 and GEOS-4 are in the convective parameterizations, cloud optical depths, and cloud top heights. These differences have been outlined in several stud- 

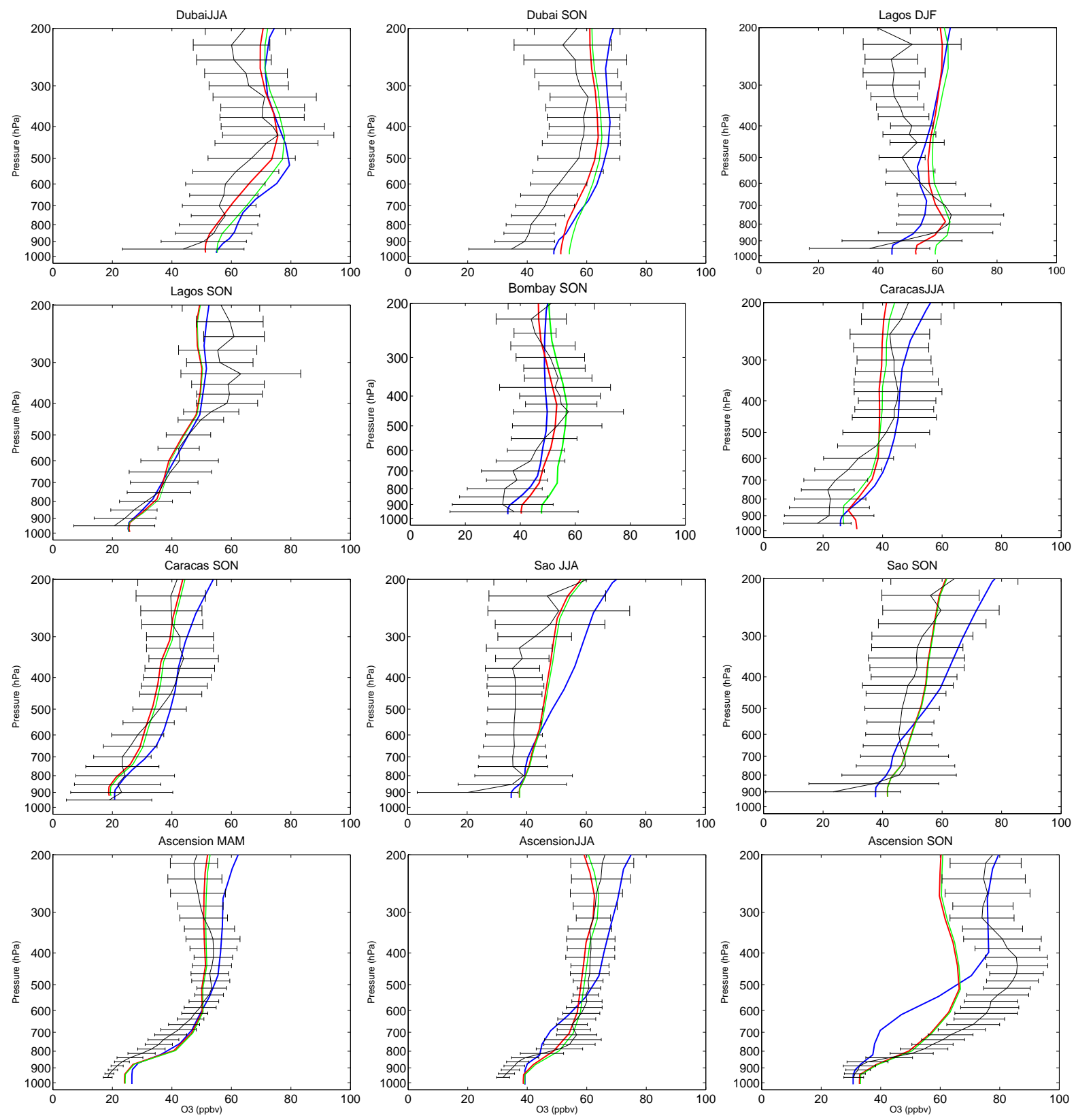

Fig. 10. Vertical profiles of $\mathrm{O}_{3}$ at MOZAIC and SHADOZ sites that exhibit a large sensitivity to either dynamics and heterogeneous chemistry. The red line is for the modified simulation (GEOS-4), the blue line for the modified simulation using GEOS-3, and the green line for $\mathrm{HNO}_{3}$ uptake turned off.

ies. As discussed by Folkins et al. (2006) the tropical cloud divergence is quite weak at all altitudes with GEOS-3, and is stronger in the upper troposphere with GEOS-4 model. Cloud optical depths are smaller in GEOS-4 than GEOS-3 leading to more active photochemistry (Liu et al., 2006; $\mathrm{Wu}$ et al., 2007). Cloud top heights are higher in GEOS-3 than GEOS-4 implying an increased altitude of injection of lightning $\mathrm{NO}_{\mathrm{x}}$ emissions.
In these simulations it is then challenging to quantify the effect of one process, as differences may result from additive or compensating multiple effects. In the following we discuss qualitatively the processes that could drive differences on chemical species distributions. We compare our modified simulation driven with GEOS-4 meteorological fields with one driven with GEOS-3 at the MOZAIC and SHADOZ sites for $\mathrm{O}_{3}$ (Fig. 10); and also for $\mathrm{CO}$ and RH (Fig. 9). For clar- 

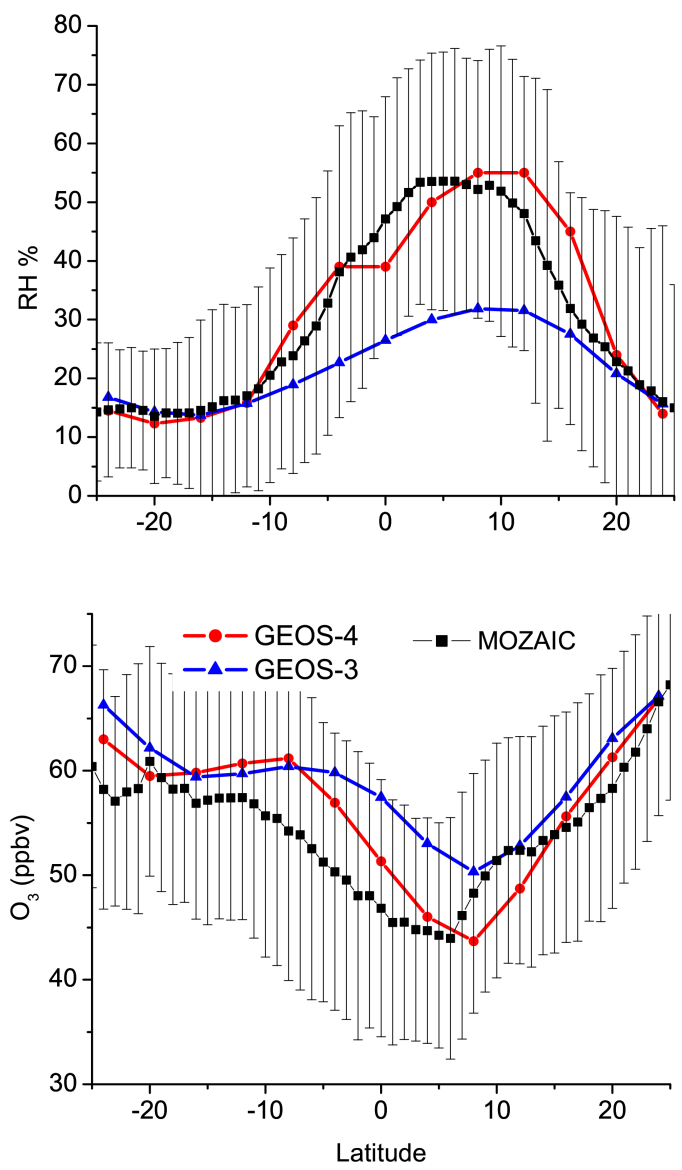

Fig. 11. Zonal average $\left(5^{\circ} \mathrm{W}-30^{\circ} \mathrm{E}\right)$ of $\mathrm{RH}$ (top) and $\mathrm{O}_{3}$ (bottom) at flight altitude (200-300 hPa) for MOZAIC (black line, squares), GEOS-4 modified (red line, circle) and GEOS-3 modified (blue line, triangle) simulations during JJA.

ity Fig. 10 contains sites and seasons that exhibited a high sensitivity to these GEOS-3 versus GEOS-4 comparisons.

The main differences in $\mathrm{O}_{3}$ between the simulations using GEOS-4 and GEOS-3 are found in the middle and upper troposphere. GEOS-3 substantially overestimates $\mathrm{O}_{3}$ compared to measurements over all regions, by $10-25 \mathrm{ppbv}(15 \%-$ $50 \%$ ) with even higher overestimates over South America, the Middle East, and the Pacific. The main difference is found over Caracas, Sao Paolo and Ascension. The major effect over subsident areas likely reflects the increased altitude of injection of lightning $\mathrm{NO}_{\mathrm{x}}$, leading to more ozone production during transport. Convective transport has considerable implications for upper tropospheric $\mathrm{CO}, \mathrm{RH}$ and $\mathrm{O}_{3}$ (Lelieveld and Crutzen, 1999; Lawrence et al., 2003; Diab et al., 2004; Folkins and Martin, 2005; Rasch et al., 1997). The remaining discrepancy above $400 \mathrm{hPa}$ could reflect an underestimate of convective detrainment of $\mathrm{O}_{3}$ depleted air (Folkins et al., 2006). The radiative effect is negligible in the upper troposphere $(<4 \%)$, consistent with Liu et al. (2006). Differences in upper tropospheric $\mathrm{RH}$ also cannot explain the
$\mathrm{O}_{3}$ differences. At $\mathrm{NO}_{\mathrm{x}}$ levels typically found in the upper troposphere, water vapor enhances net $\mathrm{O}_{3}$ production (Klonecki et al., 1997). The reduced RH in the upper troposphere in GEOS-3 would tend to decrease $\mathrm{O}_{3}$ net production reducing the $\mathrm{O}_{3}$ difference with GEOS-4.

The role of convection is apparent in a zonal average. Figure 11 shows a zonal average $\left(5^{\circ} \mathrm{W}-30^{\circ} \mathrm{E}\right)$, along MOZAIC flight altitudes, $200-300 \mathrm{hPa}$, during the monsoon season (JJA). MOZAIC data depict the ITCZ position over Africa $\left(0^{\circ}-10^{\circ} \mathrm{N}\right)$ with depleted $\mathrm{O}_{3}$ and enhanced $\mathrm{RH}$ (Sauvage et al., 2007a). GEOS-3 overestimates $\mathrm{O}_{3}$ and underestimates RH in contrast with GEOS-4.

There are a few instances where MOZAIC measurements are more consistent with GEOS-3 than with GEOS-4. For example during SON over Lagos, Ascension (Fig. 10), and Reunion, upper tropospheric $\mathrm{O}_{3}$ measurements are better reproduced with GEOS-3, than with GEOS-4. This bias at Ascension appears to reflect the low altitude of lightning outflow in GEOS-4, as supported by the improvement in the simulation with enhanced intracloud lightning. It confirms that the seasonal bias at Ascension, described on Sect. 4.1.1 reflects an issue in lightning altitude injection.

The two assimilation schemes also affect trace gases in the lower troposphere at some locations (Fig. 10, Lagos, Ascension, Bombay). The GEOS-3 simulation exhibits lower $\mathrm{O}_{3}$ concentrations than with GEOS-4 and in situ measurements. In contrast both GEOS-3 and GEOS-4 underestimate lower tropospheric CO at Lagos and Delhi (Fig. 9), but the simulation is within one standard deviation of the measurements and the CO seasonal cycle well reproduced. Both simulations are able to capture the lower tropospheric maximum in $\mathrm{CO}$ associated with the biomass burning season, in DJF and MAM over Lagos, and MAM over Delhi. In the lower troposphere GEOS-4 CO is lower than GEOS-3, likely reflecting lower cloud optical depth that results in an increase in photoloysis rates and active photochemistry, and more active convection that would transport $\mathrm{CO}$ from the lower troposphere.

The lower tropospheric $\mathrm{CO}$ underestimate with both GEOS-3 and GEOS-4, suggests an underestimate of $\mathrm{CO}$ emissions in both the modified and original simulations. We did not attempt to correct this bias. However we examine the possible implications in our $\mathrm{O}_{3}$ simulation by increasing $\mathrm{CO}$ biomass burning emissions by a factor 2 . The effect on $\mathrm{O}_{3}$ is negligible, increasing the $\mathrm{O}_{3}$ background by 3 ppbv.

More than a simple overview of two different meteorological datasets, this comparison clearly shows convection and cloud features as major processes driving tropospheric $\mathrm{O}_{3}$. These processes may be as important as the remaining uncertainties in chemical processes and emissions sources. 


\section{Conclusions}

We used a global chemical transport model (GEOS-Chem) to evaluate the consistency of multiple satellite measurements and to examine the processes affecting tropospheric $\mathrm{O}_{3}$ over the Tropics. Space-based observations from the Global Ozone Monitoring Experiment (GOME), Optical Transient Detector (OTD) and Lightning Imaging sensor (LIS) instruments are used to constrain the model emissions necessary for an accurate estimation and understanding of processes affecting tropical tropospheric ozone. In-situ measurements from the Measurements of ozone and water vapor by in-service Airbus aircraft (MOZAIC) program and the Southern Hemisphere Additional Ozonesondes (SHADOZ) ozonesonde network, were subsequently used to evaluate the simulation.

Our modified simulation featured substantial modifications over the original simulation. A climatology of flash counts from the OTD and LIS instruments is used to improve the spatial distribution of lightning $\mathrm{NO}_{\mathrm{x}}$ emissions in the model. Tropospheric $\mathrm{NO}_{2}$ and $\mathrm{HCHO}$ columns retrieved from GOME are applied to provide top-down constraints on emission inventories of $\mathrm{NO}_{\mathrm{x}}$ (biomass burning and soils) and VOCs (biomass burning). We remove $\mathrm{HO}_{2}$ uptake on biomass burning aerosols, and implement $\mathrm{HNO}_{3}$ uptake on mineral dust.

Upper tropospheric $\mathrm{O}_{3}$ is highly sensitive to the spatial distribution of lightning $\mathrm{NO}_{\mathrm{x}}$ emissions. The lightning rescaling improves the simulation of middle and upper tropospheric $\mathrm{O}_{3}$ for tropical sites, by $5-15 \mathrm{ppbv}(10 \%-45 \%)$ versus in situ measurements from SHADOZ and MOZAIC. Biases in the simulation of tropospheric ozone columns are reduced by 1-6 DU versus GOME, MOZAIC and SHADOZ measurements. We evaluate lightning emissions in terms of intensity, by testing $\pm 2 \mathrm{Tg} \mathrm{N} / \mathrm{yr}$ around the $6 \mathrm{Tg} \mathrm{N} / \mathrm{yr}$ used in the modified simulation; and in terms of distribution by increasing the $\mathrm{NO}_{\mathrm{x}}$ emitted from intracloud lightning. A lightning source strength of $6 \pm 2 \mathrm{Tg} N / \mathrm{yr}$ best represents in situ observations from MOZAIC and SHADOZ . Increasing the ratio of intra-cloud (IC) to cloud-ground (CG) lightning NO emissions from 0.1 to 0.75 generally introduces an $\mathrm{O}_{3}$ overestimate compared to in situ measurements. However, substantial improvements are found at Ascension and Reunion during SON. A global mean increase in intra-cloud lightning $\mathrm{NO}_{\mathrm{x}}$ is not supported by in situ $\mathrm{O}_{3}$ profiles. Prognostic determination of the IC/CG ratio could yield an improved simulation of tropical ozone. Further study should investigate the possibility of seasonal and spatial variations in the IC/CG ratio.

The top-down constraints on $\mathrm{NO}_{\mathrm{x}}$ emissions inferred from GOME $\mathrm{NO}_{2}$ columns increase biomass burning emissions,= by a factor of 2.6 over North Africa. The $\mathrm{NO}_{\mathrm{x}}$ emission factor inferred from GOME $\mathrm{NO}_{2}$ columns over savanna/grassland is $3.4 \mathrm{~g} \mathrm{NO} / \mathrm{kg} \mathrm{dm}, 40 \%$ higher than the recommendation by Andreae (Andreae and Merlet, 2001; An- dreae, personal communication, 2005) but within the given range. The GOME HCHO columns provide a measure of reactive VOC emissions. An increase in $\mathrm{HCHO}$ and alkenes emissions by a factor of 2 over biomass burning regions is necessary to reproduce GOME observations of $\mathrm{HCHO}$ columns. The top-down emissions increase the simulation of lower tropospheric ozone by 5-20 ppbv, improving the simulation versus MOZAIC in situ measurements, mainly over Africa where $\mathrm{O}_{3}$ is most sensitive to surface sources. The improvement in simulated $\mathrm{O}_{3}$ provides an indirect validation of the retrieved tropospheric $\mathrm{NO}_{2}$ and $\mathrm{HCHO}$ columns. The modeled TOC are within 1-3 DU of GOME, and within 1$4 \mathrm{DU}$ compared to in situ measurements. The seasonal variations are well reproduced.

We evaluate the biogenic a posteriori $\mathrm{NO}_{\mathrm{x}}$ emission inventory (Jaeglé et al., 2005) versus in situ $\mathrm{O}_{3}$ measurements. The largest influence appears over Africa and adjacent regions in MAM/JJA, with $\mathrm{O}_{3}$ increasing by 5-7 ppbv, and reducing a regional model bias.

We drive GEOS-Chem with two different assimilation schemes, GEOS-3 and GEOS-4, that feature different convective parameterizations and cloud fields. The two different dynamical schemes have considerable effect on the ozone simulation. GEOS-4 better represents $\mathrm{O}_{3}$ observations by $5-$ $20 \mathrm{ppbv}$ due to enhanced convective detrainment in the upper troposphere, compared to GEOS-3 which overestimates $\mathrm{O}_{3}$. The role of enhanced convective outflow is particularly apparent in relative humidity and $\mathrm{O}_{3}$ in the upper troposphere across the ITCZ over Africa. The two assimilated fields most affect carbon monoxide in the lower troposphere, and observations are better reproduced with GEOS-3 which has higher cloud optical depths.

Recent laboratory and field measurements provide evidence for uptake of $\mathrm{HNO}_{3}\left(\gamma_{\mathrm{HNO}_{3}}=0.1\right)$ on mineral dust, and the absence of $\mathrm{HO}_{2}$ uptake on biomass burning aerosols. We evaluate those processes with in situ measurements of $\mathrm{O}_{3} . \mathrm{HNO}_{3}$ uptake reduces a regional model bias by $5-15 \%$ downwind of deserts. The neglect of $\mathrm{HO}_{2}$ uptake on biomass burning aerosols increases simulated $\mathrm{O}_{3}$ by 5 ppbv, improving our simulations versus in situ measurements in biomass burning regions. Direct uptake of $\mathrm{O}_{3}\left(\gamma_{O_{3}}=10^{-5}\right)$ on mineral dust introduces a large model bias compared to $\mathrm{MOZAIC} \mathrm{O}_{3}$ measurements over West Africa.

We have shown that satellite observations of lightning and $\mathrm{O}_{3}$ precursors improve substantially the simulation of tropical tropospheric $\mathrm{O}_{3}$ with a global chemical transport model due to better representation of emissions. The most prominent outstanding issues are related to lightning and convection. Future development of a prognostic parameterization of lightning that reproduces observed flash counts, should improve the accuracy of $\mathrm{O}_{3}$ simulations. In-situ measurements of trace gases in close proximity to deep convection in the Tropics would enable disentangling of issues related to lightning vertical profile and convective transport. Recent high resolution space-based data, such as from Aura (Schoeberl et 
al., 2006), or MetOp-A should continue to provide additional insight into tropical tropospheric ozone.

Acknowledgements. We thank I. Folkins for insightful discussions that contributed to the manuscript. The authors acknowledge MOZAIC funding agencies, the European Commission, CNRS (France), Forschungszentrum Jülich (Germany), Météo France, EADS (Airbus) and the airlines (Air France, Lufthansa, Austrian Airlines, and former Sabena who carry free of charge the MOZAIC equipment and perform the maintenance). We also acknowledge the European Agency, ESA/ERIN. SHADOZ is supported by NASA's Atmospheric Chemistry and Analysis Program (ACMAP), Aura Validation, and the TOMS and OMI projects. We thank D. Boccippio for providing the lightning flash counts used in this analysis. We thank M. O. Andreae for providing his biomass burning emission factors data base. This work was supported by the Atmospheric Composition Program of NASA's Earth-Sun System Division.

Edited by: F. J. Dentener

\section{References}

Aghebo, A. M., Schultz, M. G., and Rast, S.: The influence of African air pollution on regional and global tropospheric chemistry, Atm. Chem. Phys. Discuss., 6, 5797-5838, 2006.

Alexander, B., Park, R. J., Jacob, D. J., et al.: Sulfate formation in sea-salt aerosols: Constraints from oxygen isotopes, J. Geophys. Res., 110, D10307, doi:10.1029/2004JD005659, 2005.

Anastasio, C. and McGregor, K. G.: Chemistry of fog waters in California's Central Valley: 1. In situ photoformation of hydroxyl radical and singlet molecular oxygen, Atmos. Environ., 35, 6, 1079-1089, 2001.

Andreae, M. O.: The influence of tropical biomass burning on climate and the atmospheric environment, in: Biogeochemistry of Global Change: Radiatively Active Trace Gases, edited by: Oremland, R. S., Chapman and Hall, New York, 113-150, 1993.

Andreae, M. O. and Merlet, P.: Emission of trace gases and aerosols from biomass burning, Global Biogeochem. Cycles, 15(4), 955966, doi:10.1029/2000GB001382, 2001.

Andreae, M. O., Artaxo, P., Fischer, H., et al.: Transport of biomass burning smoke to the upper troposphere by deep convection in the equatorial region, Geophys. Res. Lett., 28, 6, 951-954, 2001.

Andreae, M. O., Rosenfeld, D., Artaxo, P., Costa, A. A., Frank, G. P., Longo, K. M., and Silva-Dias, M. A. F.: Smoking Rain Clouds over the Amazon, Science, 303, 1337-1342, 2004.

Burrows, J. P., Weber, M., Buchwitz, M., et al.: The Global Ozone Monitoring Experiment (GOME): Mission concept and first scientific results, J. Atmos. Sci., 56, 151-175, 1999.

Bauer, S. E., Balkanski, Y., Schulz, M., Hauglustaine, D. A., and Dentener, F.: Global modeling of heterogeneous chemistry on mineral aerosol surfaces: Influence on tropospheric ozone chemistry and comparison to observations, J. Geophys. Res., 109, D02304, doi:10.1029/2003JD003868, 2004.

Bertram, T. H., Heckel, A., Richter, A., Burrows, J., and Cohen, R. C.: Satellite measurements of daily variations in soil $\mathrm{NO}_{\mathrm{x}}$ emissions, Geophys. Res. Lett., 32, L24812, doi:10.1029.2005GL024640, 2005.
Bey, I., Jacob, D. J., Yantosca, R. M., et al.: Global modeling of tropospheric Chemistry with assimilated meteorology: Model description and evaluation, J. Geophys. Res., 106, 23 073-23 096, 2001.

Bian, H. and Zender, C. S.: Mineral dust and global tropospheric chemistry: Relative roles of photolysis and heterogeneous uptake, J. Geophys. Res., 108(D21), 4672, doi:10.1029.2002JD003143, 2003.

Boccippio, D. J., Cummins, K. L., Christian, H. J., and Goodman, S. J.: Combined satellite and surface-based estimation of the intracloud cloud-to-ground lightning ratio over the continental United States, C. Mon. Wea. Rev., 129, 108-122, 2001.

Boccippio, D. J., Goodman, S. J., and Heckman, S.: Regional differences in tropical lightning distributions, J. Appl. Meteorol., 39, 2231-2248, 2000.

Boccippio, D. J., Driscoll, K. T., Koshak, W. J., Blakeslee, R. J., Boeck, W. L., Mach, D. A., Buechler, D. E., Christian, H. J., and Goodman, S. J.: The Optical Transient Detector (OTD): Instrument characteristics and cross-sensor validation, J. Atmos. Oc. Technol., 17, 441-458, 2000.

Boccippio, D. J.: Lightning scaling laws revisited, J. Atmos. Sci., 59, 1086-1104, 2002.

Boersma, K. F., Eskes, H. J., and Brinksma, E. J.: Error analysis for tropospheric $\mathrm{NO}_{2}$ retrieval from space, J. Geophys. Res., 109, D04311, doi:10.1029.2003JD003962, 2004.

Chatfield, R. B. and Delany, A. C.: Convection links biomass burning to increased tropical ozone: However, models will tend to overpredict $\mathrm{O}_{3}$, J. Geophys. Res., 95, 18 473-18 488, 1990.

Chance, K., Palmer, P. I., Spurr, R. J. D., Martin, R. V., Kurosu, T. P., and Jacob, D. J.: Satellite observations of formaldehyde over North America from GOME, Geophys. Res. Lett., 27, 34613464, doi:10.1029.2000GL011857, 2000.

Chandra, S., Ziemke, J. R., Bhartia, P. K., and Martin, R. V.: Tropical tropospheric ozone: Implications for biomass burning, J. Geophys. Res., 107(D14), doi:10.1029.2001JD000447, 2002.

Chandra, S., Ziemke, J. R., and Martin, R. V.: Tropospheric ozone at tropical and middle latitudes derived from TOMS/MLS residual: Comparison with a global model, J. Geophys. Res., 108, doi:10.1029.2002JD002912, 2003.

Christian, H. J., Blakeslee, R. J., Boccipio, D. J., Boeck, W. L., Buechler, D. E., Driscoll, K. T., Goodman, S. J., Hall, J. M., Mach, D. M., and Stewart, M. F.: Global frequency and distribution of lighning as observed from space by the Optical Transient Detector, J. Geophys. Res., 108(D1), 4005, doi:10.1029.2002JD002347, 2003.

Christian, H. J., Blakeslee, R. J., and Goodman, S. J.: The Detection of Lightning from Geostationary Orbit, J. Geophys. Res., 94, 13329-13337, 1989.

de Forster, F. P. M. and Shine, K. P.: Radiative forcing and temperature trends from stratospheric ozone changes, J. Geophys. Res., 102(D9), 10 841-10856, 1997.

DeCaria, A. J., Pickering, K. E., Stenchikov, G. L., Scala, J. R., Stith, J. L., Dye, J. E., Ridley, B. A., and Laroche, P.: A cloudscale model study of lightning-generated $\mathrm{NO}_{\mathrm{x}}$ in an individual thunderstorm during STERAO-A, J. Geophys. Res., 105(D9), 11 601-11 616, 2000.

DeCaria, A. J., Pickering, K. E., Stenchikov, G. L., and Ott, L. E.: Lightning-generated $\mathrm{NO}_{\mathrm{x}}$ and its impact on tropospheric ozone production: A three-dimensional modeling study of a 
Stratosphere-Troposphere Experiment: Radiation, Aerosols and Ozone (STERAO-A) thunderstorm: J. Geophys. Res., 110, D14303, doi:10.1029/2004JD005556, 2005.

Diab, R. D., Thompson, A. M., Mari, K., Ramsay, L., Coetzee, G. J. R.: Tropospheric ozone climatology over Irene, South Africa, from 1990 to 1994 and 1998 to 2002, J. Geophys. Res., 109, D20301, doi:10.1029/2004JD004793, 2004.

Dickerson, R. R., Rhoads, K. P., Carsey, T. P., Oltmans, S. J., Burrows, J. P., and Crutzen, P. J.: Ozone in the remote marine boundary layer: A possible role for halogens, J. Geophys. Res., 104(D17), 21 385-21 396, 1999.

Dickerson, R. R., Andreae, M. O., Campos, T., Mayol-Bracero, O. L., Neusuess, C., and Streets, D. G.: Analysis of black carbon and carbon monoxide observed over the Indian Ocean: Implications for emissions and photochemistry, J. Geophys. Res., 107(D19), 8017, doi:10.1029/2001JD000501, 2002.

Duncan, B. N., Martin, R. V., Staudt, A. C., Yevich, R. M., and Logan, J. A.: Interannual and seasonal variability of biomass burning emissions constrained by remote-sensed observations, J. Geophys. Res., 108, 4040, doi:10.1029.2002JD002378, 2003.

Edwards, D. P., Lamarque, J. F., Attié, J. L., et al.: Tropospheric ozone over the Tropical Atlantic: a satellite perspective, J. Geophys. Res., 108(D8), 4237, doi:10.1029.2002JD002927, 2003.

Evans, M. J. and Jacob, D. J.: Impact of new laboratory studies of $\mathrm{N}_{2} \mathrm{O}_{5}$ hydrolysis on global model budgets of tropospheric nitrogen oxides, ozone, and $\mathrm{OH}$, Geophys. Res. Lett., 32, L09813, doi:10.1029.2005GL022469, 2005.

Fairlie, T. D., Jacob, D. J., and Park, R. J.: The impact of transpacific transport of mineral dust in the United States Atmos. Environ., in press, 2007.

Fehr, T., Holler, H., and Huntrieser, H.: Model study on production and transport of lightning-produced NOx in a EULINOX supercell storm, J. Geophys. Res., 109, D09102, doi:10.1029.2003JD003935, 2004.

Folkins, I. and Martin, R. V.: The vertical structure of tropical convection and its impact on the budgets of water vapor and ozone, J. Atmos. Sci., 62, 5, 1560-1573, 2005.

Folkins, I., Bernath, P., Boone, C., Eldering, A., Lesins, G., Martin, R.V., Sinnhuber, B.-M., and Walker, K.: Testing convective parameterizations with tropical measurements of $\mathrm{HNO}_{3}, \mathrm{CO}, \mathrm{H}_{2} \mathrm{O}$, and $\mathrm{O}_{3}$ : implications for the water vapor budget, J. Geophys. Res., 111, D23304, doi:10.1029/2006JD007325, 2006.

Fu, T.-M., Jacob, D. J., Palmer, P. I., Chance, K., Wang, Y. X., Barletta, B., Blake, D. R., Stanton, J. C., and Pilling, M. J.: Spacebased formaldehyde measurements as constraints on volatile organic compound emissions in east and south Asia, J. Geophys. Res., in press, 2007.

Guenther, A., Karl, T., Harley, P., Wiedinmyer, C., Palmer, P. I., and Geron, C.: Estimates of global terrestrial isoprene emissions using MEGAN (Model of Emissions of Gases and Aerosols from Nature), Atmos. Chem. Phys., 6, 3181-3210, 2006, http://www.atmos-chem-phys.net/6/3181/2006/.

Guerova, G., Bey, I., Attié, J.-L., Martin, R. V., Cui, J., and Sprenger, M.: Impact of transatlantic transport episodes on summertime ozone in Europe Atmos. Chem. Phys., 6, 2057-2072, 2006 , http://www.atmos-chem-phys.net/6/2057/2006/.

Goodman, A. L., Underwood, G. M., and Grassian, V. H.: A laboratory study of the heterogeneous resaction of nitric acid on clacium carbonate particles, J. Geophys. Res., 105(D23), 29053-29 064, 2000.

Grassian, V. H.: Heterogeneous uptake and reaction of nitrogen oxides and volatile organic compounds on the surface of atmospheric particles including oxides, carbonates, soot and mineral dust: Implictions for the chemical balance of the troposphere, Int. Rev. Phys. Chem., 20(20), 467-548, 2001.

Hack, J. J.: Parameterization of moist convection in the National Center for Atmospheric Research Community Climate Model (CCM2), J. Geophys. Res., 99, 5551-5568, 1994.

Hanisch, F. and Crowley, J. N.: Ozone decomposition on Saharan dust: an experimental investigation, Atmos. Chem. Phys., 3, 119-130, 2003, http://www.atmos-chem-phys.net/3/119/2003/.

Hastenrath, S.: Climate and circulations of the tropics, D. Reidel, Dordrecht, 1985.

Heald, C. L., Jacob, D. J., Fiore, A. M., et al.: Asian outflow and trans-Pacific transport of carbon monoxide and ozone pollution: An integrated satellite, aircraft, and model perspective, J. Geophys. Res., 108(D24), 4804, doi:10.1029.2003JD003507, 2003.

Holland, E. A., Dentener, F. J., Braswel, B. H., and Sulzman, J. M.: Contemporary and pre-industrial global reactive nitrogen budgets, Biogeochem., 46, 7-43, 1999

Hoskins, B. J. and Rodwell, M. J.: A model of the Asian summer monsoon. Part I: the global scale, J. Atmos. Sci., 52, 9, 13291340, 1995.

Hudman, R. C., Jacob, D. J., Turquety, S., et al.: Surface and lightning sources of nitrogen oxides over the United States: magnitudes, chemical evolution, and outflow, J. Geophys. Res., in press, 2007.

Jaeglé, L., Martin, R. V., Chance, K., Steinberger, L., Kurosu, T. P., Jacob, D. J., Modi, A. I., Yoboué, V., Sigha-Nkamdjou, L., and Galy-Lacaux, C.: Satellite mapping of rain-induced nitric oxide emissions from soils, J. Geophys. Res., 109, D21310, doi:10.1029/2004JD004787, 2004.

Jaeglé, L., Steinberger, L., Martin, R. V., and Chance, K.: Global partitioning of $\mathrm{NO}_{\mathrm{x}}$ sources using satellite observations: Relative roles of fossil fuel combustion, biomass burning and soil emissions, Faraday Discuss., 130, 407-423, doi:10.1039.b502128f, 2005.

Jacob, D. J., Heikes, B. G., Fan, S.-M., et al.: Origin of ozone and $\mathrm{NO}_{\mathrm{X}}$ in the tropical troposphere: A photoChemical analysis of aircraft observations over the South Atlantic basin, J. Geophys. Res., 101(D19), 24 235-24 250, 1996.

Jacob, D. J.: Heterogeneous chemistry and tropospheric ozone, Atmos. Environ., 34, 2131-2159, 2000.

Kim, J. H., Na, S., Newchurch, M. J., and Martin, R. V.: Tropical tropospheric ozone morphology and seasonality seen in satellite and in situ measurements and model calculations, J. Geophys. Res., 110, D02303, doi:10.1029.2003JD004332, 2005.

Klonecki, A. and Levy II, H.: Tropospheric chemical ozone tendencies in $\mathrm{CO}-\mathrm{CH}_{4}=\mathrm{NO}_{\mathrm{y}}-\mathrm{H}_{2} \mathrm{O}$ system: Their sensitivity to variations in environmental parameters and their application to a global chemistry transport model study, J. Geophys. Res., 102(D17), 21 221-21 237, 1997.

Kurosu, T. P., Chance, K., and Spurr, R. J. D.: CRAG-cloud retrieval algorithm for ESA's global ozone monitoring experiment, ESA WPP-161, 513-521, Eur. Space Res. and Tech Cent., Noordwijk, Netherlands, 1999. 
Labrador, L. J., von Kuhlmann, R., and Lawrence, M. G.: The effects of lightning-produced NOx and its vertical distribution on atmospheric chemistry: sensitivity simulations with MATCHMPIC, Atmos. Chem. Phys., 5, 1815-1834, 2005, http://www.atmos-chem-phys.net/5/1815/2005/.

Lacis, A. A., Wuebbles, D. J., and Logan, J. A.: Radiative forcing of climate by changes in the vertical distribution of ozone, J. Geophys. Res., 95(D7), 9971-9981, 1990.

Lawrence, M. G., von Kuhlmann, R., Salzmann, M., and Rasch, P. J.: The balance of effects of deep convective mixing on tropospheric ozone, Geophys. Res. Lett., 30(18), 1940, doi:10.1029.2003GL017644, 2003.

Lee, D. S., Kohler, I., Grobler, E., Rohrer, F., Sausen, R., GallardoKlenner, L., Olivier, J. H. J., Dentener, F. J, and Bouwman, A. F.: Estimation of global $\mathrm{NO}_{\mathrm{x}}$ emissions and their uncertainties, Atmos. Environ., 31, 1735-1749, 1997.

Leue, C., Wenig, M., Wagner, T., Klimm, O., Platt, U., and Jahne, B.: Quantitative analysis of $\mathrm{NO}_{\mathrm{x}}$ emissions from Global Ozone Monitoring Experiment satellite image sequences, J. Geophys. Res., 106, 5493-5506, doi:10.1029.2000JD900572, 2001.

Lelieveld, J. and Crutzen, P. J.: Role of deep cloud convection in the ozone budget of the troposphere, Science, 264, 1759-1761, 1994.

Li, Q., Jacob, D. J., Logan, J. A., Bey, I., Yantosca, R. M., Liu, H., Martin, R. V., Fiore, A. M., Field, B. D., Duncan, B. N., and Thouret, V.: A tropospheric ozone maximum over the Middle East, Geophys. Res. Lett., 28, 3235-3238, 2001.

Liao, H. and Seinfeld,J. H.: Global impacts of gas-phase chemistryaerosol interactions on direct radiative forcing by anthropogenic aerosols and ozone, J. Geophys. Res., 110, D18208, doi:10.1029.2005JD005907, 2005.

Liu, X., Chance, K., Sioris, C. E., Spurr, R. J. D., Kurosu, T. P., Martin, R. V., and Newchurch, M. J.: Ozone profile and tropospheric ozone retrievals from the Global Ozone Monitoring Experiment: Algorithm description and validation, J. Geophys. Res., 110, D20307, doi:10.1029.2005JD006240, 2005.

Liu, X., Chance, K., Sioris, C., et al.: First directly retrieved global distribution of tropospheric column ozone from GOME: Comparison with the GEOS-Chem model, J. Geophys. Res., 111, D02308, doi:10.1029.2005JD006564, 2006.

Liu, H., Crawford, J. H., Pierce, R. B., Norris, P., Platnick, S. E., Chen, G., Logan, J. A., Yantosca, R. M., Evans, M. J., Kittaka, C., Feng, Y., and Tie, X.: Radiative effect of clouds on tropospheric chemistry in a global three-dimensional chemical transport model, J. Geophys. Res., 111, D20303, doi:10.1029/2005JD006403, 2006.

Lobert, J. M., Keene, W. C., Logan, J. A., and Yevich, R.: Global chlorine emissions from biomass burning: Reactive Chlorine Emission Inventory, J. Geophys. Res., 104(D7), 8373-8390, doi:10.1029/1998JD100077, 1999.

Logan, J. A., Prather, M. J., and Hierro, R. F.: Tropospheric chemistry - A Global perspective, J. Geophys. Res., 86, 7210-7254, 1981.

Marenco, A., Thouret, V., Nédélec, P., Smit, H., Helten, M., Kley, D., Karcher, F., Simon, P., Law, K., Pyle, J., Poschmann, G., Von Wrede, R., Hume, C., and Cook, T.: Measurement of ozone and water vapor by Airbus in-service aircraft: The MOZAIC airborne program, An overview, J. Geophys. Res., 103, 25 631-25 642, 1998.
Martin, R. V., Jacob, D. J., Logan, J. A., et al.: Interpretation of TOMS observations of tropical tropospheric ozone with a global model and in situ observations, J. Geophys. Res., 107(D18), 4351, doi:10.1029.2001JD001480, 2002a.

Martin, R. V., Chance, K., Jacob, D. J., et al.: An improved retrieval of tropospheric nitrogen dioxide from GOME, J. Geophys. Res., 107(D20), 4437, doi:10.1029.2001JD001027, 2002b.

Martin, R. V., Jacob, D. J., Chance, K., Kurosu, T. P., Palmer, P. I., and Evans, M. J.: Global inventory of nitrogen oxide emissions constrained by space-based observations of $\mathrm{NO}_{2}$ columns, J. Geophys. Res., 108(D17), 4537, doi:10.1029.2003JD003453, 2003a.

Martin, R. V., Jacob, D. J., Yantosca, R. M., Chin, M., and Ginoux, P.: Global and regional decreases in tropospheric oxidants from photochemical effects of aerosols, J. Geophys. Res., 108(D3), 4097, doi:10.1029.2002JD002622, 2003b.

Martin, R. V., Parrish, D. D., Ryerson, T. B., Nicks Jr., D. K., Chance, K., Kurosu, T. P., Jacob, D. J., Sturges, E. D., Fried, A., and Wert, B. P.: Evaluation of GOME satellite measurements of tropospheric $\mathrm{NO}_{2}$ and $\mathrm{HCHO}$ using regional data from aircraft campaigns in the southeastern United States, J. Geophys. Res., 109, D24307, doi:10.1029.2004JD004869, 2004.

Martin, R. V., Sauvage, B., Folkins, I., Sioris, C. E., Boone, C., Bernath, P., and Ziemke, J.: Space-based constraints on the production of nitric oxide by lightning, J. Geophys. Res., in press, 2007.

Meyer-Arnek, J., Ladstatter-Weissenmayer, A., Richter, A., Wittrock, F., and Burrows, J. P.: A study of the trace gas columns of $\mathrm{O}_{3}, \mathrm{NO}_{2}$, and $\mathrm{HCHO}$ over Africa in September 1997, Faraday Discuss., 130, 387-405, 2005.

Michel, A. B., Usher, C. R., and Grassian, V. H.: Heterogeneous and catalytic uptake of ozone on mineral oxides and dusts: A Knudsen cell investigation, Geophys. Res. Lett., 29, 14, 1665, doi:10.1029.2002GL014896, 2002.

Millet, D. B., Jacob, D. J., Turquety, S., Hudman, R. C., Wu, S., Fried, A., Walega, J., Heikes, B. G., Blake, D. R., Singh, H. B., Anderson, B. E., and Clarke, A. D.: Formaldehyde distribution over North America: Implications for satellite retrievals of formaldehyde columns and isoprene emission, J. Geophys. Res., 111, D24S02, doi:10.1029/2005JD006853, 2006.

Moorthi, S. and Suarez, M. J.: Relaxed Arakawa-Schubert - A parameterization of moist convection for general-circulation models Mon. Wea. Rev., 120, 6, 978-1002, 1992.

Nesbitt, S. W., Zhang, R., and Orville, R. E.: Seasonal and Global $\mathrm{NO}_{\mathrm{x}}$ production by lightning estimated from the Optical Transient Detector (OTD), Tellus, 52B, 1206-1215, 2000.

Nédélec, P. , Cammas, J. -P., Thouret, V., Athier, G., Cousin, J.-M., Legrand, C., Abonnel, C., Lecoeur, F., Cayez, G., and Marizy C.: An improved infrared carbon monoxide analyser for routine measurements aboard commercial airbus aircraft: Technical validation and first scientific results of the MOZAIC III programme, Atmos. Chem. Phys., 3, 1551-1564, 2003, http://www.atmos-chem-phys.net/3/1551/2003/.

Ott, L. E., Pickering, K. E., Stenchhikov, G. L., Huntrieser, H., and Schumann, U.: Effects of lightning $\mathrm{NO}_{\mathrm{x}}$ production during the July 21 EULINOX storm studied with a 3 -D cloud-scale chemical transport model: J. Geophys. Res., in press, 2007.

Palmer, P. I., Jacob, D. J., Chance, K., Martin, R. V., Spurr, R. J. D., Kurosu, T. P., Bey, I., Yantosca, R., Fiore, A., and Li, 
Q.: Air mass factor formulation for spectroscopic measurements from satellites: Application to formaldehyde retrievals from the Global Ozone Monitoring Experiment, J. Geophys. Res., 106(D13), 14 539-14 550, 2001.

Palmer, P. I., Jacob, D. J., Fiore, A. M. , Martin, R. V., Chance, K., and Kurosu, T. P.: Mapping isoprene emissions over North America using formaldehyde column observations from space, J. Geophys. Res., 108(D6), 4180, doi:10.1029.2002JD002153, 2003.

Palmer, P. I., Abbot, D. S., Fu, T.-M., et al.: Quantifying the seasonal and interannual variability of North American isoprene emissions using satellite observations of the formaldehyde column, J. Geophys. Res., 111, D12315, doi:10.1029/2005JD006689, 2006.

Park, R. J., Jacob, D .J., Field, B. D., Yantosca, R. M., and Chin, M.: Natural and transboundary pollution influences on sulfate-nitrate-ammonium aerosols in the United States: implications for policy, J. Geophys. Res., 109, D15204, doi:10.1029/2003JD004473, 2004.

Park, R. J., Jacob, D. J., Palmer, P. I., Clarke, A. D., Weber, R. J., Zondlo, M. A., Eisele, F. L., Bandy, A. R., Thornton, D. C., Sachse, G. W., and Bond, T. C.: Export efficiency of black carbon aerosol in continental outflow: global implications, J. Geophys. Res., 110, D11205, doi:10.1029/2004JD005432, 2005.

Pickering, K. E., Wang, Y. S., Tao, W. K., Price, C., and Muller, J. F.: Vertical distributions of lightning $\mathrm{NO}_{\mathrm{x}}$ for use in regional and global chemical transport models, J. Geophys. Res., 103, 31203 31 216, 1998.

Price, C. and Rind, D.: A simple lightning parameterization for calculating global lightning distributions, J. Geophys. Res., 97, 9919-9933, 1992.

Price, C., Penner, J., and Prather, M.: $\mathrm{NO}_{\mathrm{x}}$ from lightning (1). Global distribution based on lightning physics, J. Geophys. Res., 102, 5929-5941, 1997.

Rasch, P. J., Mahowald, N. M., and Eaton, B. E.: Representations of transport, convection, and the hydrologic cycle in chemical transport models: Implications for the modeling of short-lived and soluble species, J. Geophys. Res., 102(D23), 28 127-28 138, 1997.

Richter, A. and Burrows, J. P.: Tropospheric $\mathrm{NO}_{2}$ from GOME measurements, Adv. Space Res., 29(D23), 1673-1683, 2002.

Rodgers, C. D.: Inverse methods for atmospheric soundings: Theory and practice, World Sci., Hackensack, N. J., 2000.

Sauvage, B., Thouret, V., Cammas, J.-P., Gueusi, F., Athier, G., and Nédélec, P.: Tropospheric ozone over Equatorial Africa: regional aspects from the MOZAIC data, Atmos. Chem. Phys., 5, 311335,2005 ,

http://www.atmos-chem-phys.net/5/311/2005/.

Sauvage, B., Thouret, V., Thompson, A. M., Witte, J. C., Cammas, J.-P., Nédélec, P., and Athier, G.: Tropical Atlantic "Ozone Paradox" and "Zonal Wave-one" from the In-situ MOZAIC and SHADOZ Data, J. Geophys. Res., 111, D01301, doi:10.1029/2005JD006241, 2006.

Sauvage, B., Martin, R. V., van Donkelaar, A., and Ziemke, J. R.: Quantification of the factors controlling tropical tropospheric ozone and the South Atlantic maximum, J. Geophys. Res., in press, $2007 \mathrm{~b}$.

Sauvage, B., Thouret, V., Cammas, J.-P., Brioude, J., Mari, C., and Nédélec, P.: Meridional ozone gradients in the African upper troposphere, Geophys. Res. Lett., in press, 2007a.

Shim, C., Wang, Y. H., Choi, Y., Palmer, P., Abbot, D. S., and Chance, K.: Constraining global isoprene emissions with GOME formaldehyde column measurements, J. Geophys. Res., 110, D24301, doi:10.1029/2004JD005629, 2005.

Sprengnether, M., Demerjian, K. L., Donahue, N. M., and Anderson, J. G.: Product analysis of the $\mathrm{OH}$ oxidation of Isoprene and 1,3-Butadiene in the presence of NO, J. Geophys. Res., 107(D15), doi:10.1029/2001JD000716, 2002.

Stevenson, D. S., Dentener, F. J., Schultz, M. G., et al.: Multimodel ensemble simulations of present-day and nearfuture tropospheric ozone, J. Geophys. Res., 111, D08301, doi:10.1029/2005JD006338, 2006.

Schoeberl, M. R., Douglass, A. R., Hilsenrath, E., et al.: Overview of the EOS Aura Mission, IEEE Transact. Geosci. Rem. Sens., 44(5), 1066-1074, 2006.

Schumann, U. and Huntrieser, H.: The global lightning induced nitrogen oxides source, Atmos. Chem. Phys. Discuss., in press, 2007.

Spurr, R. J. D.: Simultaneous derivation of intensities and weighting functions in a general pseudo-spherical discrete ordinate radiative transfer treatment, J. Quant. Spectrosc. Radiat. Transfer, 75, 129-175, 2002.

Staudt A. C., Jacob, D. J., Ravetta, F., et al.: Sources and chemistry of nitrogen oxides over the tropical Pacific, J. Geophys. Res., 108(D2), 8239, doi:10.1029/2002JD002139, 2003.

Stehr, J. W., Ball, W. P., Dickerson, R. R., Doddridge, B. G., Piety, C. A., and Johnson, J. E.: Latitudinal gradients in $\mathrm{O}_{3}$ and CO during INDOEX 1999, J. Geophys. Res., 107(D19), 8016, doi:10.1029/2001JD000446, 2002.

Tabazadeh, A., Jacobson, M. Z., Singh, H. B., Toon, O. B., Lin, J. S., Chatfield, R. B., Thakur, A. N., Talbot, R. W., and Dibb, J. E.: Nitric acid scavenging by mineral and biomass burning aerosols, Geophys. Res. Lett., 25, 4185-4188, 1998.

Thakur, A. N., Singh, H. B., Mariani, P., et al.: Distribution of reactive nitrogen species in the remore free troposphere: data and model comparisons, Atmos. Environ., 99, 1403-1422, 1999.

Thompson, A. M.: The oxidizing capacity of the earth's atmosphere: Probable past and future changes, Science, 256, 1157$1165,1992$.

Thompson, A. M., Doddridge, B. G., Witte, J. C., Hudson, R. D., Luke, W. T., Johnson, J. E., Johnson, B. J., Oltmans, S. J., and Weller, R.: A tropical Atlantic paradox: Shipboard and satellite views of a tropospheric ozone maximum and wave-one in January-February 1999, Geophys. Res. Lett., 27, 3317-3320, 2000.

Thompson, A. M., Witte, J. C., Mc Peters, R. D., et al.: Southern Hemisphere Additional Ozonesondes (SHADOZ) 19982000 tropical ozone climatology 2. Tropospheric variability and the zonal wave-one, J. Geophys. Res., 108(D2), 8238, doi:10.1029/2001JD000967, 2003b.

Thompson, A. M., Witte, J. C., Oltmans, S. J., et al.: Southern Hemisphere Additional Ozonesondes (SHADOZ) 1998-2000 tropical ozone climatology 1. Comparison with Total Ozone Mapping Spectrometer (TOMS) and groundbased measurements, J. Geophys. Res., 108(D2), 8241, doi:10.1029/2002JD002241, 2003a.

Thouret, V., Cammas, J.-P., Sauvage, B., Athier, G., Zbinden, R., Nédélec, P., Simon, P., and Karcher, F.: Southern Hemisphere 
Tropopause referenced ozone climatology and inter-annual variability (1994-2003) from the MOZAIC programme, Atmos. Chem. Phys., 6, 1033-1051, 2006, http://www.atmos-chem-phys.net/6/1033/2006/.

Thornton, J. and Abbatt, J. P. D.: Measurements of $\mathrm{HO}_{2}$ uptake to aqueous aerosol: Mass accommodation coefficients and net reactive loss, J. Geophys. Res., 110(D8), D08309, doi:10.1029/2004JD005402, 2005.

Umann, B., Arnold, F., Schaal, C., Hanke, M., Uecker, J., Aufmhoff, H., Balkanski, Y., and Van Dingenen, R.: Interaction of mineral dust with gas phase nitric acid and sulfur dioxide during the MINATROC II field campaign: First estimate of the uptake coefficient $\gamma \mathrm{HNO}_{3}$ from atmospheric data, J. Geophys. Res., 110, D22306, doi:10.1029/2005JD005906, 2005.

Underwood, G. M., Song, C. H., Phadnis, M., Carmichael, G. R., and Grassian, V. H.: Heterogeneous reactions of $\mathrm{NO}_{2}$ and $\mathrm{HNO}_{3}$ on oxides and mineral dust: A combined laboratory and modeling study, J. Geophys. Res., 106(D16), 18 055-18 066, 2005.

van Noije, T. P. C., Eskes, H. J., Dentener, F. J., et al.: Multimodel ensemble simulations of tropospheric $\mathrm{NO}_{2}$ compared with GOME retrievals for the year 2000, Atmos. Chem. Phys., 6, 2943-2979, 2006,

http://www.atmos-chem-phys.net/6/2943/2006/.
Wang, Y., Jacob, D. J., and Logan, J. A.: Global simulation of tropospheric $\mathrm{O}_{3}-\mathrm{NO}_{\mathrm{x}}$-hydrocarbon chemistry, 1 - Model formulation, J. Geophys. Res., 103, 10713-10726, 1998.

Wang, K. Y. and Shallcross, D. E.: Modelling terrestrial biogenic isoprene fluxes and their potential impact on global chemical species using a coupled LSM-CTM model, Atmos. Environ., 34, 2909-2925, 2000.

Wu, S., Mickley, L. J., Jacob, D. J., Logan, J. A., and Yantosca, R. M.: Why are there large differences between models in global budgets of tropospheric ozone?, J. Geophys. Res., in press, 2007.

Yamasoe, M. A., Artaxo, P., Miguel, A. H., and Allen, A. G.: Chemical composition of aerosols particles from direct emissions of vegetation fires in the Amazon Basin: water-soluble species and trace elements Atmos. Env., 34(10), 1641-1653, 2000.

Yienger, J. J. and Levy II, H.: Empirical model of global soilbiogenic $\mathrm{NO}_{\mathrm{x}}$ emissions, J. Geophys. Res., 100(D6), 11447 $11464,1995$.

Zhang, G. J. and McFarlane, N. A.: Sensitivity of climate simulations to the parameterization of cumulus in the Canadian Climate Centre General Circulation Model, Atmosphere-Ocean, 33, 407 446, 1995. 